\title{
Donepezil in Alzheimer's disease: an evidence-based review of its impact on clinical and economic outcomes
}

\author{
Joanne Knowles
}

Core Medical Publishing, Knutsford, UK

\begin{abstract}
Introduction: Donepezil is indicated for the symptomatic treatment of mild to moderate Alzheimer's disease. It is a specific and reversible inhibitor of acetylcholinesterase (AChE); by increasing levels of available acetylcholine, donepezil may compensate for the loss of functioning cholinergic brain cells.

Aims: This review evaluates the clinical impact of donepezil by assessing randomized controlled and open-label naturalistic trials, as well as observational studies. A broad perspective is gained of its effectiveness on various outcomes.

Evidence review: There is strong evidence that donepezil has efficacy against the three major domains of Alzheimer's disease symptoms, namely functional ability, behavior, and cognition. The strongest evidence is for improvement or less deterioration in global outcomes and cognition in the short to medium term. There is limited evidence that improved global outcomes are maintained in the long term and clear evidence to support long-term maintenance of cognitive benefits. Also, donepezil appears to maintain function in the long term and there is some level 1 and 2 evidence of improved or limited deterioration in behavior or mood in the short to medium term. Despite donepezil's effects on major symptoms of Alzheimer's disease, its impact on patients' quality of life has not been consistently demonstrated, perhaps reflecting the difficulty of assessing this aspect in this patient population. Donepezil may also lessen caregiver burden. Donepezil has some effect on markers of brain function, but more data are needed to confirm a neuroprotective effect. There is limited and conflicting evidence that long-term donepezil treatment delays time to institutionalization. There is some evidence that donepezil may be cost effective, especially when unpaid caregiver costs are considered. Donepezil is generally safe and well tolerated.

Clinical value: AChE inhibitors are the only agents recommended for the treatment of cognitive decline in patients with mild to moderate Alzheimer's disease. Donepezil is more effective than placebo and is well tolerated in improving the major symptoms of this disease. Improvements are usually modest, although stabilization of cognitive and functional symptoms with donepezil can also be considered an important clinical outcome. Donepezil may lessen caregiver burden. Donepezil may also be cost effective, especially when unpaid caregiver costs are considered. More data are required from randomized controlled trials with long-term follow-up to confirm its cost effectiveness and impact on quality of life, disease progression, and time to institutionalization.
\end{abstract}

Key words: acetylcholinesterase (AChE) inhibitor, Alzheimer's disease, dementia, donepezil, evidence, outcomes

Core evidence clinical impact summary for donepezil in mild to moderate Alzheimer's disease

\begin{tabular}{|lll|}
\hline Outcome measure & Evidence & Implications \\
\hline $\begin{array}{l}\text { Patient-oriented evidence } \\
\text { Global }\end{array}$ & & \\
$\begin{array}{l}\text { Improvement in global outcomes in the short to } \\
\text { medium term }\end{array}$ & Substantial & $\begin{array}{l}\text { Donepezil is more effective than placebo in improving global outcomes in the short to } \\
\text { medium term }\end{array}$ \\
$\begin{array}{l}\text { Maintenance of improvements in global } \\
\text { outcomes in the long term }\end{array}$ & Limited & $\begin{array}{l}\text { Donepezil may be more effective than placebo in maintaining global outcomes in the long } \\
\text { term }\end{array}$ \\
$\begin{array}{l}\text { Stabilization of symptoms in the long term } \\
\text { Donepezil treatment stabilizes cognitive and functional symptoms in comparison with } \\
\text { placebo in the long term }\end{array}$ & Substantial & $\begin{array}{l}\text { Dentinued overleaf... } \\
\end{array}$ \\
\end{tabular}




\begin{tabular}{|c|c|c|}
\hline \multicolumn{3}{|l|}{...table continued } \\
\hline Outcome measure & Evidence & Implications \\
\hline \multicolumn{3}{|l|}{ Cognition } \\
\hline $\begin{array}{l}\text { Improvement in cognition in the short to medium } \\
\text { term }\end{array}$ & Substantial & $\begin{array}{l}\text { Donepezil produces modest improvements in cognition in comparison with placebo in the } \\
\text { short to medium term }\end{array}$ \\
\hline $\begin{array}{l}\text { Maintenance of improvements in cognition in the } \\
\text { long term }\end{array}$ & Clear & $\begin{array}{l}\text { Donepezil maintains improvements in cognition in comparison with placebo in the long } \\
\text { term }\end{array}$ \\
\hline \multicolumn{3}{|l|}{ Function } \\
\hline $\begin{array}{l}\text { Improvement in function (activities of daily living) } \\
\text { in the short to medium term }\end{array}$ & Some & $\begin{array}{l}\text { Donepezil may be more effective than placebo in improving function in the short to } \\
\text { medium term }\end{array}$ \\
\hline $\begin{array}{l}\text { Improvement in function (activities of daily living) } \\
\text { in the long term }\end{array}$ & Substantial & $\begin{array}{l}\text { Donepezil produces improved or less deterioration in functional ability in comparison with } \\
\text { placebo in the long term }\end{array}$ \\
\hline \multicolumn{3}{|l|}{ Behavior/mood } \\
\hline $\begin{array}{l}\text { Improvement in behavior/mood in the short to } \\
\text { medium term }\end{array}$ & Some & $\begin{array}{l}\text { Donepezil is more effective than placebo in improving or limiting deterioration in behavior } \\
\text { or mood in the short to medium term }\end{array}$ \\
\hline Improvement in behavior/mood in the long term & No evidence & \\
\hline \multicolumn{3}{|l|}{ Tolerability } \\
\hline Tolerability & Substantial & $\begin{array}{l}\text { Donepezil is well tolerated; the most common adverse events are predictable from its } \\
\text { cholinergic mechanism of action }\end{array}$ \\
\hline $\begin{array}{l}\text { Lower incidence of adverse events in a } \\
\text { naturalistic trial setting }\end{array}$ & Some & The incidence of adverse effects may be lower outside of the clinical trial setting \\
\hline \multicolumn{3}{|l|}{ Other } \\
\hline Delayed disease progression & Insufficient & Donepezil does not have an effect on the progression of disability or death rates \\
\hline Delayed time to institutionalization & Limited & Further confirmation of effectiveness required \\
\hline Improvement in quality of life & Insufficient & Evidence is divided on whether donepezil improves quality of life \\
\hline Caregiver burden lessened & Some & Donepezil may lessen caregiver burden in terms of caring time spent each day \\
\hline \multicolumn{3}{|l|}{ Disease-oriented evidence } \\
\hline Delayed disease progression & Some & $\begin{array}{l}\text { Donepezil has an effect on indirect markers of disease progression, such as regional } \\
\text { cerebral blood flow, }{ }^{123} \text { I quinuclidinyl benzilate, quantitative electroencephalogram, and } \\
\text { the degree of hippocampal atrophy, in comparison with matched control groups }\end{array}$ \\
\hline \multicolumn{3}{|l|}{ Economic evidence } \\
\hline Cost effectiveness in Alzheimer's disease patients & Some & Donepezil may be cost effective, especially when unpaid caregiver costs are considered \\
\hline
\end{tabular}

\section{Scope, aims, and objectives}

Donepezil (Aricept ${ }^{\circledR}$, Eisai and Pfizer) is indicated for the symptomatic treatment of mild to moderate Alzheimer's disease. It is a specific and reversible inhibitor of acetylcholinesterase (AChE), thus inhibiting acetylcholine hydrolysis. By maintaining levels of acetylcholine, donepezil may help compensate for the loss of functioning cholinergic neurons in Alzheimer's disease.

Of the available AChE inhibitors (AChEls), only tacrine (Cognex ${ }^{\circledR}$ ) has been on the market longer than donepezil; tacrine was approved in 1993 but is rarely prescribed today because of associated adverse events, including possible liver damage. Donepezil was approved in 1996/1997, and rivastigmine (Exelon ${ }^{\circledR}$ ) and galantamine (Razadyne ${ }^{\circledR} /$ Reminyl $^{\circledR}$ ) were approved in 2000 and 2001, respectively.
This article audits the clinical impact of donepezil by assessing the results of randomized controlled and open-label naturalistic trials, as well as observational studies. A broad perspective is gained of its effectiveness on outcomes that include global outcomes, cognition, function, behavior/mood, disease progression, time to institutionalization, quality of life, caregiver burden, and tolerability.

Use in patients with mild cognitive impairment or severe Alzheimer's disease was excluded, as these indications are not presently approved. However, as indicated in the tables, some of the included reviews and studies combined results from patients with mild, moderate, and severe Alzheimer's disease, and it was not possible to separate data from patients with mild to moderate symptoms. 


\section{Methods}

Searches of the English language literature were conducted between March 21 and 31, 2005, on August 2, 2005, and September 12, 2005, in the following databases. The search strategy was "donepezil AND (Alzheimer OR dementia)" unless otherwise stated. The cut-off date was from the beginning of the database to the date of the search unless otherwise stated.

\section{- PubMed, http://www.ncbi.nlm.nih.gov/entrez/query.fcgi}

- Database of Abstracts of Reviews of Effects (DARE), National Health Service (NHS) Economic Evaluation Database (NHSEED), Health Technology Assessment (HTA), http://www.york.ac.uk/inst/crd/darehp.htm. All three databases were searched together. All fields searched

- NHS HTA, http://www.ncchta.org

- National Guideline Clearing House, http://www.guideline.gov

- National Institute for Health and Clinical Excellence (NICE), http://www.nice.org.uk

- Cochrane Database of Systematic Reviews (CDSR), http://www.cochrane.org/index0.htm

- Clinical Evidence (BMJ), http://www.clinicalevidence.com

After removal of duplicates, a total of 613 records were retrieved from the PubMed, DARE, NHSEED, HTA, and NHS HTA databases. Records were manually reviewed and a total of 467 records were excluded: nonsystematic reviews $(n=202)$; animal or mechanism of action studies $(n=35)$; studies in patients other than Alzheimer's disease patients, or Alzheimer's disease not specified, or Alzheimer's disease in Down's syndrome patients $(n=109)$; studies in patients with severe or advanced Alzheimer's disease $(n=10)$; letters, editorials, comment, and corrections $(n=66)$; articles that mentioned donepezil but did not investigate its clinical use, or donepezil results were not reported separately $(n=19)$; studies assessing the prediction of response to treatment $(n=12)$; and studies of donepezil treatment cessation or switch to another treatment $(n=14)$. The remaining 146 records were included in the review.

Three sets of clinical guidelines were identified from the National Guidelines Clearinghouse (APA 1997; Doody et al. 2001b; California Workgroup 2002). The NICE Appraisal Consultation Document for Alzheimer's disease (NICE 2005), the Cochrane Collaboration review of donepezil for dementia due to Alzheimer's disease (Birks \& Harvey 2003), and the Clinical Evidence review of dementia (Warner et al. 2004) were also included as systematic reviews. The NICE Appraisal Consultation Document for Alzheimer's disease was issued in March 2005 and was prepared for comment from formal consultees (NICE 2005). Preliminary guidance was issued in January 2006 (NICE 2006). The Cochrane Collaboration review and Clinical Evidence review of dementia were duplicated in the PubMed database. Therefore, a total of 150 records were included in the review (Table 1 ).

\section{Table 1 | Evidence base included in the review}

\begin{tabular}{|lc|}
\hline Category & Number of records (full papers) \\
\hline Initial search & 617 \\
records excluded & 467 \\
records included & 150 \\
Level 1 clinical evidence & 20 \\
Level 2 clinical evidence & 23 \\
Level $\geq 3$ clinical evidence & 98 \\
trials other than RCT & 79 \\
case reports & 19 \\
Clinical guidelines & 3 \\
Economic evidence & 6 \\
\hline For definition of levels of evidence, see Editorial Information on inside back cover. \\
RCT, randomized controlled trial.
\end{tabular}

For each outcome, preference was given to level 1 and 2 evidence (see Editorial Information on inside back cover). However, as the review aimed to gain a broad perspective of the effectiveness of donepezil on outcomes, level 3 and 4 evidence was also assessed, particularly where level 1 and 2 evidence was lacking or conflicting. Outcomes from original level 2 or 3 studies, covered in level 1 evidence, were not considered separately in this review. As a result, 12 level 2 papers (Rogers \& Friedhoff 1996; Rogers et al. 1998a; Rogers et al. 1998b; Burns et al. 1999; Greenberg et al. 2000; Homma et al. 2000; Mohs et al. 2001; Tariot et al. 2001; Winblad et al. 2001; Wilkinson et al. 2002; Tune et al. 2003; Wilcock et al. 2003) and three level 3 papers (Rogers \& Friedhoff 1998; Rogers et al. 2000; Doody et al. 2001a), which presented data on outcomes for which substantial level 1 evidence was identified, are not considered in this review.

\section{Disease overview}

Alzheimer's disease is a type of dementia characterized by deterioration in functional ability [activities of daily living (ADL)], behavior and mood, and cognition and memory. It is a progressive disorder that usually develops slowly but steadily over a period of several years. Its onset is frequently after 65 years of age and, as age advances, its incidence increases rapidly, approximately doubling every 5 years (WHO 2001). Median survival from initial diagnosis is approximately 4-6 years, which is about half as long as survival among people of a similar age without dementia (Larson et al. 2004).

\section{Diagnosis}

There is no simple test that provides a definitive diagnosis of Alzheimer's disease. Also, the onset of Alzheimer's is often so gradual and the early signs so mild that they can easily be mistaken for normal mental aging. However, it is important to diagnose Alzheimer's disease as early as possible to give those affected by the disease and their caregivers the opportunity to 
prepare for disease progression, and to increase the likelihood of gaining benefit from existing treatments.

Diagnosis depends largely on the elimination of other systemic, psychiatric, and neurologic causes of dementia by clinical and laboratory investigation. This is accompanied by a careful assessment of the family and personal history of the individual and their symptoms. The classic clinical features of Alzheimer's disease can be categorized into three domains: function (ADL), behavior, and cognition. Loss of higher level function involving complex decision making and activities (e.g. managing finances) is followed in advanced phases by abnormalities of basic ADL, such as eating, grooming, and using the toilet (reviewed by Cummings 2004). Behavioral disturbances also progress, and mood change and apathy are early markers of the disease. Psychosis and agitation are characteristic of the middle or late phases of the disease (Cummings 2004). Moreover, primary caregivers, who are usually family members, are documented to suffer frequently from stress, insomnia, and fatigue and as a consequence may require medical care themselves (Leung et al. 2003).

The scales used most frequently in clinical trials to measure the three key symptom domains in Alzheimer's disease include:

- function (ADL): Progressive Deterioration Scale (PDS), Instrumental Activities of Daily Living (IADL), Disability Assessment for Dementia (DAD), Katz ADL

- behavior: Neuropsychiatric Inventory (NPI), Behavioral Pathology in Alzheimer's Disease (BEHAVE-AD)

- cognition: cognitive part of the Alzheimer's Disease Assessment Scale (ADAS-cog), Mini Mental State Examination (MMSE).

Scales to measure severity are also used frequently to indicate effects on disease progression, such as the Clinical Dementia Rating (CDR) scale, and Global Deterioration Scale (GDS). These symptom and severity scales are readily available but suffer from variability due to examiner subjectivity. More objective techniques that can be used to confirm diagnosis by excluding dementia due to other causes include computed tomography (CT), magnetic resonance imaging (MRI), and positron emission tomography (PET) of the brain. The definitive pathologic hallmarks of Alzheimer's disease, the presence of amyloid plaques and neurofibrillary tangles, can only be detected currently by examining the brain at postmortem.

\section{Prevalence}

Estimated values for the prevalence of Alzheimer's disease vary from 1 to $5 \%$, partly because of differences in age samples and diagnostic criteria among the studies conducted (WHO 2001). A World Health Organization (WHO) study estimated a prevalence of $5 \%$ for men and $6 \%$ for women in those above 60 years (WHO 2001); it is thought that more women than men are encountered with Alzheimer's disease because of greater female longevity. A separate study estimated that $6.1 \%$ of the worldwide population aged 65 years and older had Alzheimer's disease or another form
Table 2 | Predicted increases in the percentage of population aged 65 years and over from the year 2000 to 2030 (adapted from Kinsella \& Velkoff 2001)

\begin{tabular}{|lcc|}
\hline Region & \multicolumn{2}{c|}{ Percentage population aged $\geq \mathbf{6 5}$ years } \\
\cline { 2 - 3 } & 2000 (actual) & 2030 (projected) \\
\hline Europe & 15.5 & 24.3 \\
North America & 12.6 & 20.3 \\
Oceania & 10.2 & 16.3 \\
Asia & 6.0 & 12.0 \\
Latin America/Caribbean & 5.5 & 11.6 \\
Near East/North Africa & 4.3 & 8.1 \\
Sub-Saharan Africa & 2.9 & 3.7 \\
\hline
\end{tabular}

of dementia in 2000 (Wimo et al. 2003a). The prevalence of Alzheimer's disease increases dramatically with age; of individuals aged between 75 and 84 years, up to $20 \%$ may be affected, while a prevalence of nearly $50 \%$ has been reported in those aged over 85 years (Evans et al. 1989).

The prevalence of Alzheimer's disease in the USA is predicted to increase from 4.5 million in 2000 to 13.2 million by 2050 (Hebert et al. 2003). This trend is likely to be repeated in many other countries where numbers of people aged over 65 years are expected to increase and be accompanied by disproportionate increases in dementia. For example, in 2000, the percentage of population aged 65 and over was $15.5 \%$ in Europe and $12.6 \%$ in North America (Kinsella \& Velkoff 2001). The projected percentages for 2030 are 24.3 and $20.3 \%$, respectively (Table 2). Moreover, significant increases in the numbers of older people are expected in developing countries, many of whose populations are aging at a much faster rate than in the developed world (Kinsella \& Velkoff 2001). Therefore, the contribution of Alzheimer's disease to the global burden of disease is likely to increase in the coming years.

\section{The burden of illness}

The progression of Alzheimer's disease is accompanied by significant losses in cognitive and functional ability; consequently, many patients require a high level of care. Also, as median survival after diagnosis is 4-6 years (Larson et al. 2004), care is usually required long term. The shift from institutional to community care in many countries has increased the burden placed on family caregivers, who are often elderly relatives (Alzheimer's Society 2004). For example, a UK survey ("Right from the start") of over 2000 caregivers of patients with dementia found that $49 \%$ were over 70 years old (Alzheimer's Society 2004). The caregiver burden encompasses physical, psychologic or emotional, social, and financial problems, and these problems appear to be experienced frequently. In the "Right from the start" survey, $60 \%$ of caregivers reported that they were suffering ill health or psychologic problems as a direct result of caring (Alzheimer's Society 2004). 
The value of services provided by unpaid caregivers is significant; in the UK, an estimate of the value in 2001-2002 was $£ 57.4$ billion (Alzheimer's Society 2004). In the USA, the average lifetime cost of care for an individual with Alzheimer's disease was estimated at \$US170 000, of which an average \$US12 500 was paid by caregivers themselves (Alzheimer's Association 2004). Many caregivers have to use private savings and assets to meet the cost of caring for a relative, and to pay for practical help and support such as home care or respite care (Alzheimer's Association 2004; Alzheimer's Society 2004). Also, caregivers in paid work may lose out on income and promotion while those who give up work risk losing work skills, pension rights, and opportunities for reemployment (Alzheimer's Society 2004). An Alzheimer's Association report estimates that Alzheimer's disease costs American businesses more than \$US61 billion a year, of which \$US24.6 billion covers Alzheimer's disease healthcare and \$US36.5 billion covers costs related to caregivers, including lost productivity, absenteeism, and worker replacement (Koppel 2002).

Alzheimer's disease also incurs a significant burden in terms of medical, institutional, and welfare resources. A report commissioned by the Alzheimer's Association in the USA predicted that by 2010 Medicare costs for beneficiaries with Alzheimer's disease would increase 54.5\%, from \$US31.9 billion in 2000 to \$US49.3 billion (Alzheimer's Association 2001). Additionally, Medicaid expenditures on residential dementia care would increase $80 \%$, from $\$$ US18.2 billion to $\$$ US33 billion in 2010 (Alzheimer's Association 2001).

\section{Pathophysiology}

Alzheimer's disease is characterized by shrinkage of the brain due to cell loss, especially in the areas concerned with memory, rational thought, and language development (St George-Hyslop 2000). Theories for the cause of brain cell loss have suggested a role for factors such as tau-protein abnormalities (Liou et al. 2003), metals (Casadesus et al. 2004), vascular factors (Fernando \& Ince 2004), and viral infections (Ringheim \& Conant 2004). One theory in particular has increasing support: the "amyloid cascade hypothesis," which suggests that the production and accumulation of beta-amyloid peptide plays a key role (Cummings 2004; Zlokovic et al. 2005). The observations that support beta-amyloid as the common initiating factor in Alzheimer's disease include the following:

- all Alzheimer's disease patients have many amyloid plaques containing degenerating nerve endings, and their plaque count far exceeds that found in normal aging (Perry et al. 1978)

- the amount of amyloid plaques in "thinking" regions of the brain correlates in some studies with the degree of mental impairment (Cummings \& Cotman 1995)

- the genes now known to cause Alzheimer's disease have been shown to increase beta-amyloid production (APP, encoding amyloid precursor protein; PSEN, encoding presenilin) or deposition (ApoE4, encoding apolipoprotein E4) (Gandy 2005).

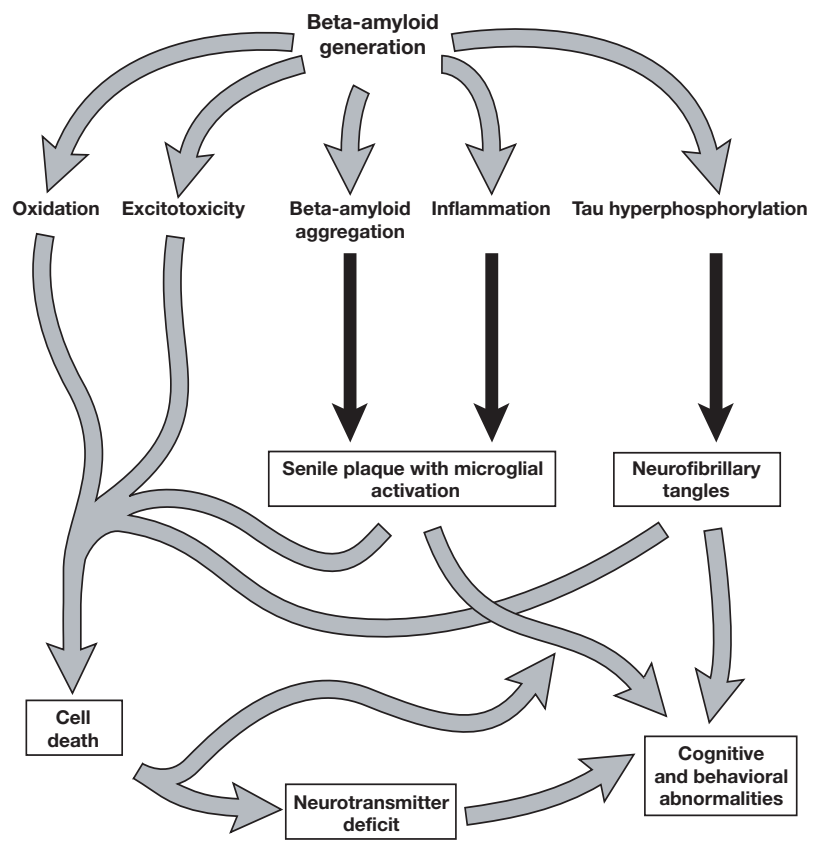

Fig. 1 | The amyloid cascade hypothesis (adapted from Cummings 2004)

Beta-amyloid protein is thought to exert neurotoxic effects via secondary mechanisms, including the formation of neurofibrillary tangles, oxidation and lipid peroxidation, glutamatergic excitotoxicity, inflammation, and activation of apoptotic cell death (Cummings 2004; Zlokovic et al. 2005) (Fig. 1). Among nuclear groups of neurons responsible for maintenance of specific transmitter systems, cell dysfunction and cell death lead to deficits in the neurotransmitters acetylcholine, norepinephrine, and serotonin (Palmer et al. 1988; Pappas et al. 2000; Cummings 2004).

Observations of damage and deficits in the cholinergic system provided the rationale for the development of AChEls, which inhibit the hydrolysis of acetylcholine. By increasing levels of available acetylcholine, AChEls may help to compensate for the loss of functioning cholinergic neurons.

\section{Current therapy options}

There is no cure for Alzheimer's disease, but there are treatments that may improve symptoms and may even delay their progression in the early and middle stages of the disease, allowing patients to maintain certain daily functions for longer. Various country- or region-specific, evidence-based guidelines have been developed for the treatment of Alzheimer's disease. These make recommendations that vary according to available resources, funding practices, and local practice. In general, however, the guidelines provide recommendations regarding psychiatric management, psychosocial treatments, and the treatment of specific target symptoms. 


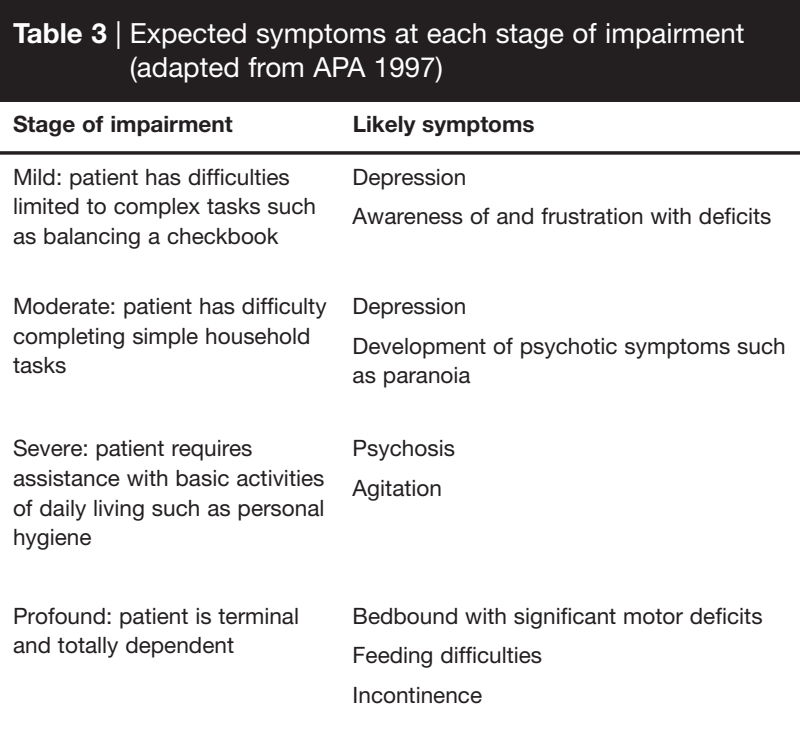

In this section, the content of several guidelines developed in the USA is described (APA 1997; Doody et al. 2001b; California Workgroup 2002). These guidelines emphasize the need for regular monitoring of symptoms to allow treatment plans to evolve and address newly emerging issues associated with this progressive condition (APA 1997; California Workgroup 2002). Also, as patients with Alzheimer's disease display a broad range of functional, cognitive, and behavioral symptoms, an individualized and multimodal treatment plan is required (APA 1997; Doody et al. 2001b; California Workgroup 2002).

\section{General treatment principles}

The first step recommended in guidelines is the development of a treatment plan taking into account the stage of illness and severity of problems (APA 1997; California Workgroup 2002). At each stage of impairment, certain symptoms should be anticipated (Table 3), and the patient and their family should be helped to plan for future symptoms.

A number of nonpharmacologic or environmental interventions may help some patients with dementia. Although limited research data are available to support their use, clinical practice suggests that improved symptoms may occur with behavior-, stimulation-, emotion-, and cognition-oriented interventions (APA 1997). Treatments directed at caregivers, including supportive psychotherapy, support groups, and respite care, are likely to be helpful to the caregiver and consequently may benefit patients as well.

\section{Cognitive decline}

Specific symptoms targeted for treatment include cognitive decline, psychosis and agitation, depression, and sleep disturbances. For the treatment of cognitive decline, guidelines recommend the use of AChEls in patients with mild to moderate
Alzheimer's disease (APA 1997; Doody et al 2001b; California Workgroup 2002). Review of guideline recommendations for the treatment of other specific target symptoms is beyond the scope of this article.

Four AChEls (tacrine, galantamine, rivastigmine, and donepezil) are available. Tacrine is rarely used now because of hepatotoxicity (Rabins 2004), so its characteristics are not reviewed in this article. Other standard prescribed agents for the symptomatic treatment of Alzheimer's disease include memantine and vitamin E. Memantine is an uncompetitive low-to-moderate affinity $N$-methyl-D-aspartate (NMDA) receptor antagonist that regulates glutamate activity. It was approved in 2003 for the treatment of cognition in moderate to severe Alzheimer's disease and, as it is relatively new to the market, memantine is not yet included in existing evidence-based treatment guidelines.

Vitamin $\mathrm{E}$ is recommended by guidelines as a treatment to delay time to clinical worsening (APA 1997; Doody et al 2001b). However, recent data (Petersen et al. 2005) conflict with evidence in support of this indication (Tabet et al. 2000).

The treatment effects and disadvantages of rivastigmine, galantamine, memantine, and vitamin E are summarized in Table 4.

\section{Unmet needs}

Review of the characteristics of treatments included in Table 4 shows that various unmet needs remain for the symptomatic treatment of mild to moderate Alzheimer's disease. Although the AChEls rivastigmine and galantamine have demonstrated consistent gains on cognitive and global scales compared with placebo, these gains have been described as small on many of the measures of effect (NICE 2005). However, in addition to improvements, AChEl treatment can have a stabilizing effect on cognitive and other symptoms (Giacobini 2000). The clinical significance of this stabilizing effect requires further investigation.

Randomized controlled trial (RCT) evidence on outcomes of importance to patients and caregivers, such as quality of life and time to institutionalization, is limited and largely inconclusive (NICE 2005). There is no strong evidence that any of the standard prescribed agents in Alzheimer's disease alters the course of the disease. Also, assessment of the adverse event profile of the AChEls suggests improved tolerability as another area of unmet need.

Donepezil is indicated for the symptomatic treatment of mild to moderate Alzheimer's disease and can be given once daily (Anon. 2005a). Generally, the initial dose is $5 \mathrm{mg} /$ day, usually given at night. After 4-6 weeks, if it is well tolerated, the dose is often increased to $10 \mathrm{mg} /$ day (see Dosage, administration, and formulations), although both the $5 \mathrm{mg}$ and $10 \mathrm{mg}$ doses are clinically effective. Donepezil has been available for 8-9 years and a large number of publications from clinical trials and studies conducted in community-based settings provide sources of clinical evidence. 
Table 4 | Other standard prescribed agents for the symptomatic treatment of Alzheimer's disease

\begin{tabular}{|c|c|c|c|c|c|c|c|c|}
\hline \multirow[t]{2}{*}{ Drug } & \multirow{2}{*}{$\begin{array}{l}\text { Disease } \\
\text { severity }\end{array}$} & \multirow[t]{2}{*}{ Drug class } & \multicolumn{5}{|c|}{ Outcome } & \multirow[t]{2}{*}{ Disadvantages } \\
\hline & & & Cognition & ADL (function) & Behavior/mood & $\begin{array}{l}\text { Disease } \\
\text { progression }\end{array}$ & $\begin{array}{l}\text { Caregiver } \\
\text { burden/time to } \\
\text { institutionalization }\end{array}$ & \\
\hline \multirow[t]{3}{*}{$\begin{array}{l}\text { Rivastigmine } \\
\text { (high dose: } \\
6-12 \mathrm{mg} \\
\text { daily) }\end{array}$} & \multirow[t]{3}{*}{$\begin{array}{l}\text { Mild to } \\
\text { moderate }\end{array}$} & \multirow[t]{3}{*}{$\begin{array}{l}\text { Cholinesterase } \\
\text { inhibitor }\end{array}$} & \multirow[t]{3}{*}{$\begin{array}{l}\text { Significant } \\
\text { improvements on } \\
\text { ADAS-cog } \\
\text { score }^{\mathrm{a}, \mathrm{b}} \text {, MMSE } \\
\text { score }^{\mathrm{b}} \text {, and } \\
\text { CIBIC-plus scale }^{\mathrm{b}}\end{array}$} & \multirow{3}{*}{$\begin{array}{l}\text { Significant } \\
\text { improvement in } \\
\text { function } \\
\text { although one of } \\
\text { four RCTs } \\
\text { showed no } \\
\text { significant } \\
\text { difference from } \\
\text { placebo on PDS }\end{array}$} & \multirow[t]{3}{*}{$\begin{array}{l}\text { No benefit } \\
\text { reported }^{\mathrm{b}}\end{array}$} & \multirow{3}{*}{$\begin{array}{l}\text { No evidence that } \\
\text { rivastigmine alters } \\
\text { the course of the } \\
\text { underlying } \\
\text { dementing } \\
\text { process }^{c}\end{array}$} & $\begin{array}{l}\text { Reduced caregiver } \\
\text { burden shown in } \\
\text { open- } \\
\text { label/observational } \\
\text { studies }^{\text {b }}\end{array}$ & \multirow{3}{*}{$\begin{array}{l}\text { Significantly } \\
\text { higher numbers } \\
\text { of AEs vs } \\
\text { placebo at high } \\
\text { dose } \\
\text { (particularly } \\
\text { nausea and } \\
\text { vomiting). Led } \\
\text { to withdrawals } \\
\text { in studies } \\
\text { Adb } \\
\text { Administered } \\
\text { bidc }^{\text {a }}\end{array}$} \\
\hline & & & & & & & \multirow{2}{*}{$\begin{array}{l}\text { Delayed time to } \\
\text { nursing home } \\
\text { placement shown } \\
\text { in open-label/ } \\
\text { observational } \\
\text { studies }^{\mathrm{b}}\end{array}$} & \\
\hline & & & & & & & & \\
\hline \multirow[t]{2}{*}{ Galantamine } & \multirow[t]{2}{*}{$\begin{array}{l}\text { Mild to } \\
\text { moderate }\end{array}$} & \multirow[t]{2}{*}{$\begin{array}{l}\text { Cholinesterase } \\
\text { inhibitor }\end{array}$} & \multirow[t]{2}{*}{$\begin{array}{l}\text { Significant } \\
\text { improvements on } \\
\text { ADAS-cog } \\
\text { score }, \text { d, } \\
\text { Improvements in } \\
\text { CIBC-plus scale } \\
\text { in individual } \\
\text { studies, although } \\
\text { not statistically } \\
\text { significant with } \\
\text { pooled data }\end{array}$} & \multirow[t]{2}{*}{$\begin{array}{l}\text { Statistically } \\
\text { significantly less } \\
\text { deterioration than } \\
\text { those on placebo } \\
\text { for doses } \\
\text { between } 16 \text { and } \\
32 \mathrm{mg} / \text { day }^{\mathrm{b}}\end{array}$} & \multirow[t]{2}{*}{$\begin{array}{l}\text { In one trial, } \\
\text { higher doses } \\
\text { ( } \geq 16 \mathrm{mg} / \text { day) } \\
\text { associated with } \\
\text { statistically } \\
\text { significant } \\
\text { slowing in } \\
\text { deterioration of } \\
\text { condition on NPI. } \\
\text { In two trials, no } \\
\text { significant } \\
\text { difference }^{b}\end{array}$} & \multirow[t]{2}{*}{$\begin{array}{l}\text { No evidence that } \\
\text { galantamine alters } \\
\text { the course of the } \\
\text { underlying } \\
\text { dementing } \\
\text { process }^{e}\end{array}$} & \multirow[t]{2}{*}{$\begin{array}{l}\text { Pooled analysis of } \\
\text { two 6-month RCTs } \\
\text { suggested a } \\
\text { statistically } \\
\text { significant } \\
\text { decrease in overall } \\
\text { mean amount of } \\
\text { time caregivers } \\
\text { spent assisting } \\
\text { people with ADL }\end{array}$} & $\begin{array}{l}\text { Across the } \\
\text { RCTs, 2-27\% } \\
\text { more } \\
\text { participants on } \\
\text { galantamine } \\
\text { suffered from } \\
\text { an AE } \\
\text { compared with } \\
\text { placebo. } \\
\text { Withdrawals } \\
\text { due to AEs } \\
\text { were } \\
\text { associated with } \\
\text { a loss of } \\
6-44 \% \text { of } \\
\text { galantamine } \\
\text { participants }\end{array}$ \\
\hline & & & & & & & & $\begin{array}{l}\text { Contraindicated } \\
\text { in patients with } \\
\text { severe hepatic } \\
\text { or renal } \\
\text { impairment }^{e}\end{array}$ \\
\hline \multirow[t]{3}{*}{ Memantine } & \multirow[t]{3}{*}{$\begin{array}{l}\text { Moderate } \\
\text { to severe }\end{array}$} & \multirow[t]{3}{*}{$\begin{array}{l}\text { NMDA } \\
\text { receptor } \\
\text { antagonist }\end{array}$} & \multirow[t]{3}{*}{$\begin{array}{l}\text { Statistically } \\
\text { significantly less } \\
\text { deterioration as } \\
\text { measured by the } \\
\text { SIB, but } \\
\text { deterioration as } \\
\text { measured by } \\
\text { MMSE not } \\
\text { significantly } \\
\text { different between } \\
\text { treatment and } \\
\text { control groups }^{b}\end{array}$} & \multirow[t]{3}{*}{$\begin{array}{l}\text { Statistically } \\
\text { significantly less } \\
\text { deterioration as } \\
\text { measured by the } \\
\text { ADCS-ADL19/sev } \\
\text { scale }^{\text {b }}\end{array}$} & \multirow[t]{3}{*}{$\begin{array}{l}\text { People receiving } \\
\text { memantine plus } \\
\text { donepezil had } \\
\text { statistically } \\
\text { significantly lower } \\
\text { NPI score } \\
\text { compared with } \\
\text { donepezil alone }{ }^{b} \text {. } \\
\text { No significant } \\
\text { difference in trial } \\
\text { of memantine } \\
\text { alone }^{b}\end{array}$} & \multirow[t]{3}{*}{$\begin{array}{l}\text { No evidence that } \\
\text { memantine } \\
\text { prevents or slows } \\
\text { neurodegeneration } \\
\text { in patients with } \\
\text { Alzheimer's } \\
\text { disease }^{f}\end{array}$} & \multirow[t]{3}{*}{$\begin{array}{l}\text { People taking } \\
\text { memantine } \\
\text { required } \\
\text { significantly less } \\
\text { caregiver time }\end{array}$} & $\begin{array}{l}\text { Although the } \\
\text { frequency of } \\
\text { AEs was similar } \\
\text { in memantine } \\
\text { and control } \\
\text { groups, rate of } \\
\text { withdrawal due } \\
\text { to AEs was } \\
\text { relatively high in } \\
\text { the memantine } \\
\text { group }\end{array}$ \\
\hline & & & & & & & & $\begin{array}{l}\text { Not } \\
\text { recommended } \\
\text { in patients with } \\
\text { severe renal } \\
\text { impairment }^{f}\end{array}$ \\
\hline & & & & & & & & $\begin{array}{l}\text { Maintenance } \\
\text { dose } \\
\text { administered } \\
\text { bid }^{f}\end{array}$ \\
\hline
\end{tabular}




\begin{tabular}{|c|c|c|c|c|c|c|c|c|}
\hline \multicolumn{9}{|c|}{...table continued } \\
\hline \multirow[t]{2}{*}{ Drug } & \multirow{2}{*}{$\begin{array}{l}\text { Disease } \\
\text { severity }\end{array}$} & \multirow[t]{2}{*}{ Drug class } & \multicolumn{5}{|c|}{ Outcome } & \multirow[t]{2}{*}{ Disadvantages } \\
\hline & & & Cognition & ADL (function) & Behavior/mood & $\begin{array}{l}\text { Disease } \\
\text { progression }\end{array}$ & $\begin{array}{l}\text { Caregiver } \\
\text { burden/time to } \\
\text { institutionalization }\end{array}$ & \\
\hline \multirow[t]{3}{*}{ Vitamin E } & \multirow[t]{3}{*}{ Moderate } & \multirow[t]{3}{*}{ Antioxidant } & \multirow[t]{3}{*}{$\begin{array}{l}\text { Not possible to } \\
\text { interpret reported } \\
\text { resultsg }\end{array}$} & \multirow[t]{3}{*}{$\begin{array}{l}\text { Not possible to } \\
\text { interpret reported } \\
\text { results }\end{array}$} & \multirow[t]{3}{*}{$\begin{array}{l}\text { Not possible to } \\
\text { interpret reported } \\
\text { results }^{g}\end{array}$} & $\begin{array}{l}\text { Limited evidence } \\
\text { that vitamin } \mathrm{E} \\
\text { reduced mortality } \\
\text { and progression } \\
\text { of dementia }\end{array}$ & \multirow{3}{*}{$\begin{array}{l}\text { Limited evidence } \\
\text { that vitamin E } \\
\text { reduced } \\
\text { institutionalizationg } \\
\end{array}$} & \multirow{3}{*}{$\begin{array}{l}\text { Excess of falls } \\
\text { in the vitamin } \mathrm{E} \\
\text { group } \\
\text { compared with } \\
\text { placebo } \\
\text { requires further } \\
\text { evaluationg }^{\text {evalion with }} \\
\text { Interaction } \\
\text { other } \\
\text { medications } \\
\text { including } \\
\text { anticoagulants }\end{array}$} \\
\hline & & & & & & \multirow{2}{*}{$\begin{array}{l}\text { No significant } \\
\text { difference in rate } \\
\text { of progression } \\
\text { between vitamin E } \\
\text { and placebo } \\
\text { over } 3 \text { years in } \\
\text { subjects with } \\
\text { MCI }^{h}\end{array}$} & & \\
\hline & & & & & & & & \\
\hline \multicolumn{9}{|c|}{$\begin{array}{l}\text { aBirks et al. } 2000 . \\
\text { 'NICE } 2005 . \\
\text { 'Exelon Prescribing Information (Anon. 2005c). } \\
\text { 'Loy \& Schneider } 2004 . \\
\text { eReminyl Prescribing Information (Anon. 2005e). } \\
\text { 'Namenda Prescribing Information (Anon. 2005d). } \\
\text { 9Tabet et al. } 2000 \text {. } \\
\text { hPetersen et al. } 2005 \text {. } \\
\text { ADAS-cog, cognitive part of the Alzheimer's Disease Assessment Scale; ADCS-ADL19, 19-item Alzheimer's Disease Cooperative Study Activities of Daily Living inventory; ADL, activities of daily } \\
\text { living; AE, adverse event; bid, twice daily; CIBIC-plus, Clinician's Interview-Based Impression of Change plus caregiver input; MCl, mild cognitive impairment; MMSE, Mini Mental State } \\
\text { Examination; NMDA, N-methyl-D-aspartate; NPI, Neuropsychiatric Inventory; PDS, Progressive Deterioration Scale; RCT, randomized controlled trial; SIB, Severe Impairment Battery. }\end{array}$} \\
\hline
\end{tabular}

\section{Clinical evidence for donepezil in Alzheimer's disease}

\section{Outcome measures}

Alzheimer's disease is characterized by deterioration in functional ability, behavior, and cognition (see Disease overview). While some scales quantify these patient-oriented outcomes by assessing status in one or more of these domains, others attempt to quantify a patient's overall or global health state with respect to Alzheimer's disease (Wolfson et al. 2000). Table 5 lists the scales that have been used most frequently in trials of donepezil in mild to moderate Alzheimer's disease. These scales have evidence of reliability and validity, and have been used widely in studies of other Alzheimer's disease treatments (Wolfson et al. 2000). However, it should be acknowledged that assessment via different domains is somewhat artificial. For example, cognitive function cannot be dissociated easily from ADLs. Also, the relation of statistical significance to clinical significance is a matter of debate in the field as is the clinical benefit of symptom stabilization. For example, there is some opinion that a change in ADAS-cog score of 3-4 points per year or change in MMSE of 2 points per year is of detectable clinical significance (A. Wimo, personal communication). Similarly, treatment may have no apparent clinical benefit in that symptoms are only stabilized but patient deterioration may follow cessation of treatment.

\section{Global outcomes}

There is level 1 evidence that donepezil is effective in improving and maintaining global outcomes in the short to medium term
(12-24 weeks). There appears to be a clear treatment effect, since these findings are consistent on three scales: the Clinical Global Impression of Change (CGIC), Clinician's Interview-Based Impression of Change plus caregiver input (CIBIC-plus), and the sum of boxes of the Clinical Dementia Rating (CDR-SB) scale (Table 6). Also, there was significant benefit with both the $5 \mathrm{mg} /$ day and $10 \mathrm{mg} /$ day doses of donepezil, with no clear dosedependent differences. Six systematic reviews found statistically significant differences from placebo in groups treated with donepezil 5 or $10 \mathrm{mg} /$ day in up to seven RCTs (Pryse-Phillips et al. 2001; Clegg et al. 2002; Wolfson et al. 2002; Birks \& Harvey 2003; Warner et al. 2004; NICE 2005; Table 6). In a meta analysis of individual patient data from 10 RCTs (Whitehead et al. 2004), the odds of improvement in CIBIC-plus scores was approximately twice as great with donepezil 5 or $10 \mathrm{mg} /$ day as with placebo at 12 and 24 weeks.

This strong evidence is supported by a large open-label trial conducted to investigate the efficacy of donepezil in a routine setting in clinical practice (Froelich et al. 2004). On the CGIC scale, nearly $80 \%$ of 186 patients showed an improvement or remained stable at week 24 relative to baseline; $54 \%$ showed little to much improvement, $25 \%$ were stable, and $17 \%$ were minimally worse.

There is limited evidence to show that the effect of donepezil on global outcomes is maintained beyond 24 weeks. One study of longer duration was identified in a systematic review (Birks \& Harvey 2003). This 52-week, double-blind, parallel-group RCT included 286 patients with mild to moderate Alzheimer's disease treated with donepezil $5 \mathrm{mg} /$ day for 28 days and then $10 \mathrm{mg} / \mathrm{day}$ (according to the clinician's judgment) or placebo. Global 
Table $\mathbf{5}$ | Scales used most frequently in trials of donepezil in mild to moderate Alzheimer's disease (Katz et al. 1963; Wolfson et al. 2000; Birks \& Harvey 2003)

\begin{tabular}{|c|c|c|c|}
\hline Outcome & Measure & Description & Scoring \\
\hline \multirow[t]{2}{*}{ Global } & $\begin{array}{l}\text { Clinical Global Impression of Change (CGIC), } \\
\text { Clinician's Interview-Based Impression of } \\
\text { Change (CIBIC) }\end{array}$ & $\begin{array}{l}\text { Measures general physical and mental } \\
\text { condition of patients, including functional ability } \\
\text { with respect to ADL, cognition, behavior, mood. } \\
\text { CIBIC-plus includes caregiver input }\end{array}$ & $\begin{array}{l}\text { Seven-point scale to measure improvement } \\
\text { (1=very much improved, } 7=\text { very much worse) }\end{array}$ \\
\hline & $\begin{array}{l}\text { Clinical Dementia Rating-sum of boxes } \\
\text { (CDR-SB) }\end{array}$ & $\begin{array}{l}\text { Measures cognitive performance in six areas: } \\
\text { memory, orientation, judgment/problem } \\
\text { solving, community affairs, home/hobbies, } \\
\text { personal care }\end{array}$ & $\begin{array}{l}\text { Each category scored on five-point scale of } \\
\text { impairment }(0=\text { none, } 0.5=\text { questionable, } 1=\text { mild, } \\
2=\text { moderate, } 3=\text { severe). The sum of ratings } \\
(0-18) \text { provides the CDR-SB }\end{array}$ \\
\hline \multirow[t]{2}{*}{ Cognitive } & Mini Mental State Examination (MMSE) & $\begin{array}{l}\text { Includes } 11 \text { questions on orientation, memory, } \\
\text { concentration, language, and praxis }\end{array}$ & $\begin{array}{l}\text { Scale ranges from } 0 \text { to } 30 \text {, a higher score } \\
\text { indicating less impairment }\end{array}$ \\
\hline & $\begin{array}{l}\text { Cognitive part of the Alzheimer's Disease } \\
\text { Assessment Scale (ADAS-cog) }\end{array}$ & $\begin{array}{l}\text { Includes } 11 \text { items on orientation, memory, } \\
\text { language, and praxis }\end{array}$ & $\begin{array}{l}\text { Scale ranges from } 0 \text { to } 70 \text {, a higher score } \\
\text { indicating greater dysfunction }\end{array}$ \\
\hline \multirow[t]{3}{*}{ Functional } & Progressive Deterioration Scale (PDS) & $\begin{array}{l}\text { Examines ADL and instrumental ADL in } \\
11 \text { areas, e.g. extent to which patient can } \\
\text { leave immediate neighborhood, use of familiar } \\
\text { household implements, involvement in family } \\
\text { finances and budgeting, self-care, and routine } \\
\text { tasks }\end{array}$ & $\begin{array}{l}\text { Scale ranges from } 0 \text { to } 100 \text {, a higher score } \\
\text { indicating better functioning }\end{array}$ \\
\hline & Instrumental Activities of Daily Living (IADL) & $\begin{array}{l}\text { Measures competence in complex ADL, } \\
\text { including telephoning, shopping, food } \\
\text { preparation, housekeeping, laundering, use of } \\
\text { transportation, use of medicine, ability to } \\
\text { handle money }\end{array}$ & $\begin{array}{l}\text { Each behavioral area is scored } 1 \text { or } 0 \text {. Higher } \\
\text { score indicates better performance }\end{array}$ \\
\hline & Katz activities of daily living (ADL) index & $\begin{array}{l}\text { Assesses ability to perform ADL independently } \\
\text { in six functions of bathing, dressing, toileting, } \\
\text { transferring, continence, and feeding }\end{array}$ & $\begin{array}{l}\text { Scored yes/no for independence in each } \\
\text { function. Total score of } 6 \text { indicates full function, } \\
2 \text { or less indicates severe functional impairment }\end{array}$ \\
\hline $\begin{array}{l}\text { Behavior/ } \\
\text { mood }\end{array}$ & Neuropsychiatric Inventory (NPI) & $\begin{array}{l}\text { Evaluates } 10 \text { items: delusions, hallucinations, } \\
\text { dysphoria, anxiety, agitation, euphoria, apathy, } \\
\text { irritability, disinhibition, aberrant motor behavior } \\
\text { (pacing and rummaging). Two more items may } \\
\text { also be assessed - night-time behavior, and } \\
\text { changes in appetite and eating behaviors }\end{array}$ & $\begin{array}{l}\text { Frequency of behavioral disturbances rated on } \\
\text { four-point scale, severity rated on three-point } \\
\text { scale. Higher total score indicates more } \\
\text { behavioral problems }\end{array}$ \\
\hline
\end{tabular}

outcomes were assessed using the Gottfries-Brane-Steen (GBS) scale. At 52 weeks, the mean difference from placebo was -6.01 , an improvement with borderline statistical significance $(P=0.05)$.

\section{Cognition}

There is strong evidence that donepezil treatment improves cognition and that these improvements are maintained in the short to medium term (12-24 weeks) (Table 6). A meta analysis revealed benefits associated with donepezil 5 and $10 \mathrm{mg} /$ day compared with placebo as shown by improvements in ADAS-cog MMSE scores at 12 and 24 weeks (Birks \& Harvey 2003). Another meta analysis of trials lasting 12-24 weeks showed weighted mean differences in ADAS-cog of -2.51 for $5 \mathrm{mg} /$ day and -3.01 for $10 \mathrm{mg} /$ day donepezil compared with placebo (NICE 2005). This improvement in ADAS-cog score is broadly in line with results reported in other systematic reviews (Pryse-Phillips et al. 2001; Wolfson et al. 2002; Birks \& Harvey 2003; Warner et al.
2004) and in a meta analysis of individual patient data (Whitehead et al. 2004).

The evidence in favor of improved cognition in the short to medium term conflicts with the results of a small RCT (Hegerl et al. 2003). A 12-week study of donepezil 5 or $10 \mathrm{mg} /$ day reported no significant improvement in ADAS-cog score versus placebo, although this trial included only 40 patients (Hegerl et al. 2003). In another more recent but larger study $(n=153)$, patients received donepezil $5 \mathrm{mg} /$ day for 6 weeks, then $10 \mathrm{mg} /$ day for 18 weeks (Seltzer et al. 2004). At 24 weeks, there were significant improvements in both MMSE and ADAS-cog versus placebo $(P=0.03$ and $P=0.008$, respectively).

The effect of donepezil on cognition appears to be maintained long term. A meta analysis showed that improvements in MMSE score are maintained at 52 weeks with donepezil $10 \mathrm{mg} /$ day compared with placebo (weighted mean difference 1.84 points, 
Table 6 | Effects of donepezil on global outcomes and cognition (level 1 evidence)

\begin{tabular}{|c|c|c|c|c|c|c|}
\hline \multirow[t]{2}{*}{ Design } & \multirow{2}{*}{$\begin{array}{l}\text { Treatment, } \\
\text { dose, duration }\end{array}$} & \multicolumn{4}{|c|}{ Measure } & \multirow[t]{2}{*}{ Reference } \\
\hline & & CGIC/CIBIC-plus & CDR-SB & MMSE & ADAS-cog & \\
\hline \multirow[t]{2}{*}{$\begin{array}{l}\text { Systematic } \\
\text { review/ } \\
\text { meta } \\
\text { analysis }\end{array}$} & $\begin{array}{l}\text { DPZ } 5 \text { or } \\
10 \mathrm{mg} / \text { day, } \\
12-24 \mathrm{wk}\end{array}$ & & & & $\begin{array}{l}\text { SD vs PL (meta analysis): } \\
-2.51 \text { WMD from } \mathrm{BL} \\
\text { ( } 5 \mathrm{mg} / \text { day, } 3 \text { studies); } \\
-3.01 \mathrm{WMD} \text { from } \mathrm{PL} \\
\text { (10 mg/day, } 3 \text { studies); } \\
-2.88 \mathrm{MD} \text { from BL (dose } \\
\text { NR, } 1 \text { study) }\end{array}$ & NICE 2005 \\
\hline & $\mathrm{DPZ} \mathrm{Z}^{\mathrm{a}}$ & $\begin{array}{l}\text { SD vs PL in change from } \\
\text { BL (7 studies) }\end{array}$ & & $\begin{array}{l}\text { Trends towards improved } \\
\text { scores vs PL (8 studies) }\end{array}$ & & \\
\hline $\begin{array}{l}\text { Systematic } \\
\text { review }\end{array}$ & $\begin{array}{l}\text { DPZ } 10 \mathrm{mg} / \text { day, } \\
24 \mathrm{wk}\end{array}$ & $\begin{array}{l}\text { OR for global improvement } \\
\text { in CIBIC-plus: } 2.2\end{array}$ & & & SD vs PL: -2.9 & $\begin{array}{l}\text { Warner } \\
\text { et al. } 2004\end{array}$ \\
\hline $\begin{array}{l}\text { Meta } \\
\text { analysis }\end{array}$ & $\begin{array}{l}\mathrm{DPZ}, 5 \text { or } \\
10 \mathrm{mg} / \mathrm{day} \\
12,24 \mathrm{wk}\end{array}$ & $\begin{array}{l}\text { OR of improvement vs } \mathrm{PL} \\
\text { on CIBIC-plus: } 5 \mathrm{mg} / \text { day, } \\
12 \mathrm{wk}, 1.8 ; 10 \mathrm{mg} / \text { day, } 12 \\
\text { wk, } 1.9 ; 5 \mathrm{mg} / \text { day, } 24 \mathrm{wk} \text {, } \\
1.9 ; 10 \mathrm{mg} / \text { day, } 24 \mathrm{wk}, 2.1 \\
\text { (all } P \leq 0.001 \text { ) }\end{array}$ & & & $\begin{array}{l}\mathrm{SD} \text { vs PL: } 5 \mathrm{mg} / \mathrm{day} \text {, } \\
12 \mathrm{wk},-2.1 ; 10 \mathrm{mg} / \text { day, } \\
12 \mathrm{wk},-2.5 ; 5 \mathrm{mg} / \mathrm{day}, \\
24 \mathrm{wk},-2 ; 10 \mathrm{mg} / \text { day, } \\
24 \mathrm{wk},-3.1 \text { (all } P<0.001)\end{array}$ & $\begin{array}{l}\text { Whitehead } \\
\text { et al. } 2004\end{array}$ \\
\hline $\begin{array}{l}\text { Meta } \\
\text { analysis }\end{array}$ & $\begin{array}{l}\text { DPZ } 5 \text { or } \\
10 \mathrm{mg} / \text { day, } \\
12,24,52 \mathrm{wk}\end{array}$ & $\begin{array}{l}\text { CIBIC-plus: SD vs } P L: \\
5 \text { mg/day, } 12 \text { wk }(P=0.005) ; \\
10 \mathrm{mg} / \text { day, } 12 \text { wk } \\
(P=0.0001) ; \\
5 \mathrm{mg} / \text { day, } 24 \mathrm{wk} \\
(P \leq 0.00001) ; \\
10 \mathrm{mg} / \mathrm{day}, 24 \mathrm{wk} \\
(P \leq 0.0001)\end{array}$ & $\begin{array}{l}\text { SD vs } P L: 10 \mathrm{mg} / \text { day, } \\
12 \mathrm{wk}(P=0.05) ; \\
5 \mathrm{mg} / \text { day, } 24 \mathrm{wk} \\
(P \leq 0.00001) ; \\
10 \mathrm{mg} / \text { day, } 24 \mathrm{wk} \\
(P \leq 0.00001)\end{array}$ & $\begin{array}{l}\text { SD vs } P L: 5 \mathrm{mg} / \mathrm{kg} \text {, } \\
12 \mathrm{wk}(P \leq 0.00001) ; \\
10 \mathrm{mg} / \mathrm{day}, 12 \mathrm{wk} \\
(P \leq 0.00001) ; 5 \mathrm{mg} / \text { day, } \\
24 \mathrm{wk}(P=0.0004) ; \\
10 \mathrm{mg} / \mathrm{day}, 24 \mathrm{wk} \\
(P \leq 0.00001) ; 10 \mathrm{mg} / \text { day, } \\
52 \mathrm{wk}(P=0.006)\end{array}$ & $\begin{array}{l}\text { SD vs } P L \text {, all } P \leq 0.00001 \text { : } \\
5 \text { or } 10 \mathrm{mg} / \text { day, } \\
12 \text { or } 24 \mathrm{wk}\end{array}$ & $\begin{array}{l}\text { Birks \& Harvey } \\
2003^{b}\end{array}$ \\
\hline $\begin{array}{l}\text { Systematic } \\
\text { review }\end{array}$ & $\begin{array}{l}\text { DPZ } 5 \text { or } \\
10 \text { mg/day, NR }\end{array}$ & $\begin{array}{l}\text { SD vs } P L: P<0.05 \\
\text { (6 studies) }\end{array}$ & & & $\begin{array}{l}\text { SD vs PL: } 5 \mathrm{mg} / \mathrm{day} \text {, } \\
P \leq 0.01 \text { ( } 4 \text { studies); } \\
10 \mathrm{mg} / \mathrm{day}, P<0.001 \\
\text { (2 studies) }\end{array}$ & $\begin{array}{l}\text { Wolfson } \\
\text { et al. } 2002\end{array}$ \\
\hline \multirow{3}{*}{$\begin{array}{l}\text { Systematic } \\
\text { review }\end{array}$} & $\begin{array}{l}\text { DPZ } 5 \text { or } \\
10 \mathrm{mg} / \text { day, NR }\end{array}$ & & & & $\begin{array}{l}\text { SD vs PL (improvement) at } \\
12,18,24 \text { weeks (1 study) }\end{array}$ & \\
\hline & $\begin{array}{l}\text { DPZ } 10 \mathrm{mg} / \text { day, } \\
12 \mathrm{wk}\end{array}$ & $\begin{array}{l}\text { SD vs PL for CIBIC-plus: } \\
\text { MD } 0.4(P<0.008) \text { ( } 1 \text { study) }\end{array}$ & & $\begin{array}{l}\text { SD vs PL: MD } 1.3 \\
(P<0.004)(1 \text { study) }\end{array}$ & $\begin{array}{l}\text { SD vs PL: MD } 3.1 \\
(P<0.001)(1 \text { study })\end{array}$ & \\
\hline & $\begin{array}{l}\text { DPZ } 5 \text { mg/day, } \\
24 \text { wk }\end{array}$ & & & & SD from BL (1 study) & \\
\hline $\begin{array}{l}\text { 'Assessme } \\
\text { ADAS-cog, } \\
\text { Change; Cl } \\
\text { NSD, no st }\end{array}$ & $\begin{array}{l}\text { plus, Clinician's Inter } \\
\text { cally significant diffe }\end{array}$ & $\begin{array}{l}\text { imer's Disease Assessment Scale } \\
\text { ew-Based Impression of Change } \\
\text { רce; OR, odds ratio; PL, placeb; }\end{array}$ & . & $\begin{array}{l}\text { il; MD, mean difference; MM } \\
\text { ed controlled trial; SD, statist }\end{array}$ & $\begin{array}{l}\text { Mini Mental State Examinatio } \\
\text { ly significant difference; wk, w }\end{array}$ & $\begin{array}{l}\text { Impression of } \\
\text { R, not reported; } \\
\text { WMD, weighted }\end{array}$ \\
\hline
\end{tabular}

$P=0.006$ ) (Birks \& Harvey 2003). In the AD2000 RCT of 565 community-resident patients, improvements in MMSE score were maintained beyond 52 weeks with donepezil 5 or $10 \mathrm{mg} /$ day (Courtney et al. 2004). There was a significant improvement in average score versus placebo over 2 years, albeit a modest one (0.8 points, $P<0.0001$ ), with no significant difference between dose groups. Interpretation of results from this study, however, must take into account concerns regarding its recruitment rate and methodology (Akintade et al. 2004; Holmes et al. 2004a). Only one fifth of the planned number of patients was recruited and high discontinuation rates during the study are likely to have detrimentally affected the power of the study. Also, the study had repeated wash-out periods, and $16 \%$ of patients also had vascular dementia. 


\begin{tabular}{|c|c|c|c|c|c|}
\hline $\begin{array}{l}\text { Level of } \\
\text { evidence }\end{array}$ & Design & $\begin{array}{l}\text { Treatment, dose, } \\
\text { duration }\end{array}$ & MMSE & ADAS-cog & Reference \\
\hline 1 & Systematic review & DPZ 5-10 mg/day, 12 wk & & $\begin{array}{l}\text { NSD vs RIV } 1.5-6 \text { mg bid (MD -0.15) } \\
\text { (1 study) }\end{array}$ & $\begin{array}{l}\text { Warner et al. } \\
2004\end{array}$ \\
\hline \multirow[t]{2}{*}{2} & \multirow[t]{2}{*}{ RCT } & \multirow{2}{*}{$\begin{array}{l}\mathrm{DPZ} 10 \mathrm{mg} / \text { day or } \\
\text { vitamin } \mathrm{E} 2000 \mathrm{IU} / \text { day, } \\
30 \text { days (FC, } n=11 \text {; } \\
\text { NFC, } n=12 \text { ) }\end{array}$} & $\begin{array}{l}\text { FC, SD vs vitamin } \mathrm{E}: 21.33 \text { vs } 18.24 \\
(P=0.001)\end{array}$ & $\begin{array}{l}\text { FC, SD vs vitamin } \mathrm{E}: 29.28 \text { vs } 32.31 \\
(P=0.003)\end{array}$ & \multirow[t]{2}{*}{$\begin{array}{l}\text { Onofrj et al. } \\
2003\end{array}$} \\
\hline & & & $\begin{array}{l}\text { NFC, SD vs vitamin } \mathrm{E}: 20.05 \text { vs } 18.55 \\
(P=0.03)\end{array}$ & NFC, NSD vs vitamin $E(P=0.06)$ & \\
\hline 3 & OL & $\begin{array}{l}\text { DPZ 5-10 mg/day } \\
(\mathrm{n}=256) . \text { RIV 6-12 mg/day } \\
(\mathrm{n}=132), 9 \mathrm{mo}\end{array}$ & $\begin{array}{l}\text { Overall, SD vs BL: } 0.7 \text { at } 3 \text { mo } \\
(P<0.001) \text { and }-0.6(P=0.006) \text { at } 9 \text { mo. } \\
\text { NSD between DPZ and RIV groups }\end{array}$ & & $\begin{array}{l}\text { Mossello et al. } \\
2004\end{array}$ \\
\hline \multirow[t]{2}{*}{3} & \multirow[t]{2}{*}{$\begin{array}{l}\text { OL, matched } \\
\text { control }\end{array}$} & \multirow{2}{*}{$\begin{array}{l}\text { DPZ, NR }(n=53) \text { or TAC, } \\
\text { NR }(n=128), 1 \text { y. } \\
\text { Untreated control }(n=218)\end{array}$} & $\begin{array}{l}\text { SD vs control in change from BL: }-1.5 \\
\text { vs }-3.7(P=0.007)\end{array}$ & & \multirow[t]{2}{*}{$\begin{array}{l}\text { Doody et al. } \\
2001 c\end{array}$} \\
\hline & & & $\begin{array}{l}\text { TAC, NSD vs control in change from } \\
\text { BL: }-2.8 \text { vs }-3.7(P=0.33)\end{array}$ & & \\
\hline
\end{tabular}

Some level 3 and 4 evidence also shows that donepezil treatment reduces the rate of decline in MMSE score. In an open-label, matched control study, 205 AChEl-treated and 218 untreated Alzheimer's disease patients were compared over 1 year (Doody et al. 2001c). The decline in MMSE score was significantly less in 53 patients treated with donepezil (dose not specified) than in the untreated group $(-1.5$ vs -3.7 points, $P=0.007)$. In a 3 -year retrospective chart review (level 4 evidence) of patients given combination therapy of donepezil ( $\geq 5 \mathrm{mg} /$ day) and vitamin $E$ ( $\geq 1000 \mathrm{U} /$ day) (Klatte et al. 2003), average MMSE values decreased at 1,2 , and 3 years (average cumulative change -1.43 , -4.05 , and -6.27 , respectively). The authors report that the decline was significantly slower than in untreated patients included in the 1986-1996 Consortium to Establish a Registry for Alzheimer's Disease (CERAD) database. However, the numbers of patients treated long term in this study were small (40 had 1-year, 38 had 2-year, and 22 had 3-year follow-up). Other level 3 evidence shows decreases in MMSE score from baseline at 1 year or 18 months but, as these studies did not include untreated control groups, it is difficult to put these data into context (Saine et al. 2002; Blasko et al. 2004; Requena et al. 2004).

Donepezil appears to be at least as effective as other treatments of cognitive function, such as rivastigmine, galantamine, tacrine, and vitamin $E$ (Table 7). One systematic review reported no significant differences in cognitive function (MMSE or ADAS-cog) between donepezil and rivastigmine (12-week open-label study) or galantamine (52 week RCT) (Warner et al. 2004). In an openlabel trial of donepezil and rivastigmine, there was no significant between-group difference in change from baseline MMSE score (Mossello et al. 2004). Similarly, there were no significant differences in MMSE or ADAS-cog scores in an open-label study of patients treated with donepezil, rivastigmine, or galantamine (Aguglia et al. 2004). A difference was observed between tacrineand donepezil-treated groups in another open-label study (Doody et al. 2001c); the difference from the untreated group was significant in donepezil-treated patients $(P=0.007)$ but not in the tacrine group $(P=0.33)$. One RCT showed significant differences between donepezil- and vitamin E-treated patients in favor of donepezil in MMSE and ADAS-cog scores, the greatest differences seen in patients with fluctuating cognition (Onofrj et al. 2003). However, only 23 patients were included in this trial and the randomized part of the study was of short duration (30 days).

\section{Function}

There is level 1 evidence that donepezil treatment produces significantly improved or less deterioration in functional ability than placebo (Clegg et al. 2002; Wolfson et al. 2002; Birks \& Harvey 2003; Warner et al. 2004; Table 8). Although this finding was not statistically significant in all short-term trials (NICE 2005), there is evidence of significant benefit with long-term donepezil treatment. In a 1-year trial of donepezil $10 \mathrm{mg} /$ day, there was significant benefit versus placebo in the primary endpoint, time to clinically evident decline in function (Wolfson et al. 2002; Birks \& Harvey 2003; Warner et al. 2004). One systematic review reports that, in this study, donepezil delayed median time to primary endpoint by 5 months compared with placebo (Warner et al. 2004). 
Table 8 | Effects of donepezil on function

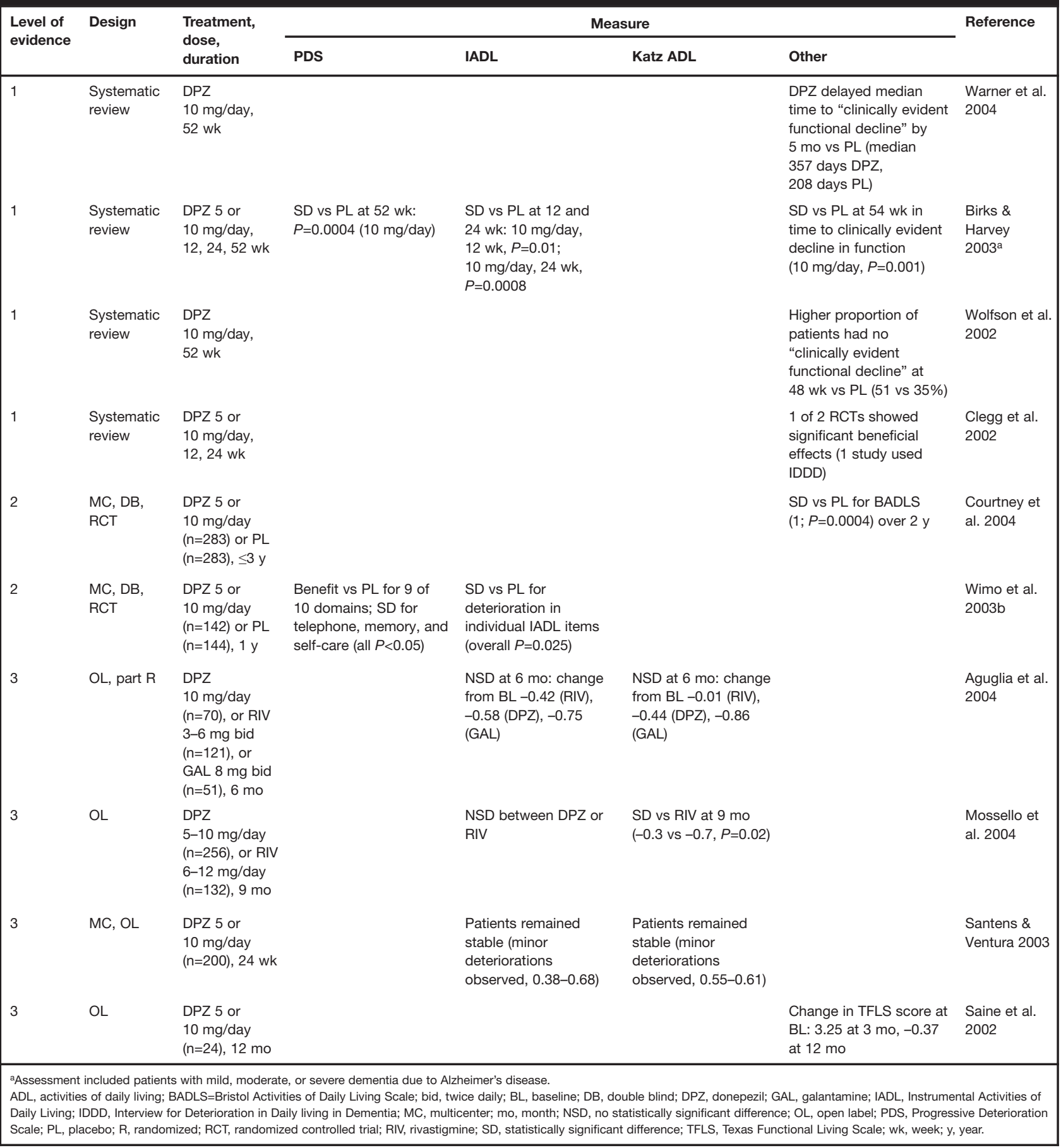

Two RCTs also found significant differences in favor of donepezil over placebo in maintaining or improving function in the long term (Table 8; Wimo et al. 2003b; Courtney et al. 2004). In one trial, subdomain analysis of the PDS at week 52 showed benefits with donepezil 5 or $10 \mathrm{mg} /$ day treatment in 9 of 10 domains (Wimo et al. 2003b). The difference from placebo reached statistical significance for the telephone $(P=0.009)$, memory $(P=0.003)$, and self-care $(P=0.042)$ items. In the same study, significantly fewer patients in the donepezil group deteriorated in individual IADL items at week 52 compared with placebo-treated patients. In the 
AD2000 study, the donepezil group had better Bristol Activities of Daily Living Scale (BADLS) scores at all timepoints after 12 weeks (Courtney et al. 2004); the average difference was 1 point better with donepezil than with placebo $(P=0.0004)$, and efficacy was maintained over 2 years. There was no significant difference between the 5 and $10 \mathrm{mg} /$ day dose groups ( $P=0.24)$.

This evidence is supported by level 3 evidence showing that patients' function remained relatively stable after up to 12 months of donepezil 5 or 10 mg/day treatment (Saine et al. 2002; Santens \& Ventura 2003; Aguglia et al. 2004; Mossello et al. 2004; Table 8). Also, donepezil appears to be at least as effective in maintaining function as other treatments, such as rivastigmine and galantamine. In a comparative study of donepezil, rivastigmine, and galantamine, there were no significant differences between groups in IADL and ADL at 6 months (Aguglia et al. 2004). Another trial found no significant difference between donepezil and rivastigmine groups in IADL score changes over time but a significantly lower decline in ADL with donepezil at 9 months $(P=0.02)$ (Mossello et al. 2004).

\section{Behavior/mood}

There is some level 1 evidence showing that donepezil has an effect in improving or limiting deterioration in behavior or mood in the short to medium term (Birks \& Harvey 2003; NICE 2005; Table 9). This is supported by level 2 evidence of significant benefit compared with placebo (Holmes et al. 2004b; Table 9). This trial began with an open-label phase of treatment with donepezil $5 \mathrm{mg} /$ day for 6 weeks followed by $10 \mathrm{mg} /$ day for a further 6 weeks. At 12 weeks, total NPI and NPI distress scores were significantly lower compared with baseline. Further improvements in NPI and NPI distress scores were observed in the medium term during the subsequent 12-week randomized part of the study, and these improvements were significant in comparison with placebo.

This evidence is supported by two open-label trials that showed improvement or stabilization of NPI scores with donepezil treatment in the short to medium term (Santens \& Ventura 2003; Tanaka et al. 2004). In a study of 70 patients, the majority showed no behavioral change after 12 weeks ( $\leq 3$-point decrease or increase in total NPI score), and nearly one third had improved symptoms ( $\geq 4$-point reduction) (Tanaka et al. 2004). In a study performed in a routine clinical setting, Santens and Ventura (2003) found no significant change in overall behavior score in 200 patients after 6 months of treatment with donepezil $5 \mathrm{mg} /$ day or $10 \mathrm{mg} /$ day. The NICE Assessment Group also comments that, in observational studies, use of donepezil appeared to show benefit on improvements in social behavior assessed by the caregiver diary (NICE 2005).

No evidence was found showing that donepezil improves or maintains behavioral symptoms long term (beyond 6 months).

\section{Disease progression}

Disease progression has been assessed by monitoring both patient- and disease-oriented outcomes. Patient-oriented outcomes include progression of disability and death rate, while disease-oriented outcomes include regional cerebral blood flow (rCBF), ${ }^{123}$ I quinuclidinyl benzilate (QNB) uptake in the brain, quantitative electroencephalogram ( $q E E G$ ), and the degree of hippocampal atrophy.

The results of two RCTs provide evidence (level 2) of an effect by donepezil on disease progression in terms of patient-oriented outcomes (Courtney et al. 2004; Petersen et al. 2005). In the AD2000 study, there were no significant benefits with donepezil compared with placebo in progression of disability at 3 years or numbers of deaths (Courtney et al. 2004). In a study of patients with mild cognitive impairment, the donepezil group (10 mg/day) had reduced likelihood of progression to Alzheimer's disease at 12 months in comparison with placebo $(P=0.04)$, but this difference was not maintained at 3 years (Petersen et al. 2005).

Lower level evidence of an impact on mortality rate is available from a retrospective matched cohort study using a database of nursing home residents in six US states (Gasper et al. 2005). A total of 5423 residents treated with donepezil were compared with 5423 nonusers of donepezil. Based on Cox proportional hazards models, donepezil users showed a lower mortality rate than nonusers [hazard rate ratio (HRR) 0.89]. This survival advantage remained after adjusting for sociodemographic factors, other psychotropic drugs, and comorbid conditions (HRR 0.9).

There is some level 2 evidence that donepezil may have an effect on the disease-oriented outcomes, rCBF (Nakano et al. 2001), 123 QNB uptake in the brain (Kemp et al. 2003), and hippocampal volume (Krishnan et al. 2003; Table 10). Treatment with donepezil $5 \mathrm{mg} /$ day reduced the decline in $\mathrm{rCBF}$, possibly indicating preservation of functional brain activity (Nakano et al. 2001). Kemp et al. (2003) demonstrated better uptake of ${ }^{123}$ QNB in patients who had received donepezil $10 \mathrm{mg} /$ day for 4 months than in those on placebo; the authors suggest this shows cholinergic treatment may have a neuroprotective role. At the end of a 24-week study of patients treated with donepezil $10 \mathrm{mg} / \mathrm{kg}$ or placebo, donepezil-treated patients had significantly smaller mean decreases in total $(P<0.01)$ and right $(P<0.02)$ hippocampal volumes (Krishnan et al. 2003). Again, these data suggest a possible neuroprotective effect of donepezil in Alzheimer's disease.

This evidence is supported by several 1-year, open-label trials that included matched control groups (Nobili et al. 2002; Rodriguez et al. 2002; Hashimoto et al. 2005; Table 10). In one study, 54 patients who received donepezil $5 \mathrm{mg} /$ day underwent MRI twice at a 1-year interval (Hashimoto et al. 2005). The results were compared with those from a matched control group of 93 untreated patients. The mean annual rate of hippocampal atrophy in the treated group was significantly lower than in the control group (3.82 vs $5.04 \%$, $P=0.008)$, suggesting a neuroprotective effect with donepezil. Similarly, rCBF was preserved in 25 patients undergoing donepezil treatment ( $5 \mathrm{mg} /$ day) for 1 year but was reduced in 13 untreated patients (Nobili et al. 2002). Long-term treatment with donepezil $5 \mathrm{mg} /$ day has also been shown to lead to lesser deterioration of qEEG in comparison with an untreated group of patients (Rodriguez et al. 2002). 


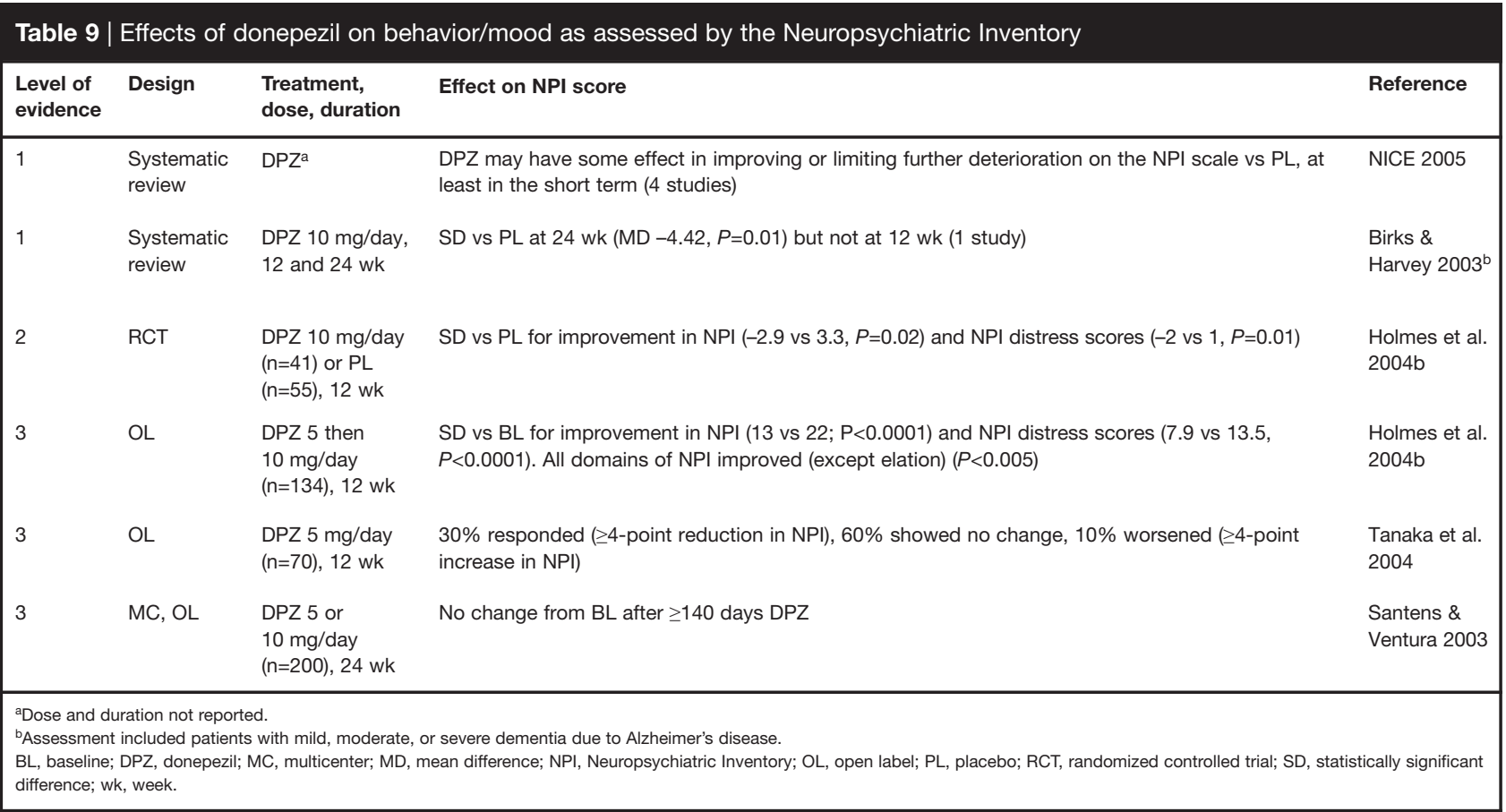

On balance, donepezil appears to have an effect on biomarkers of disease progression, but further RCT evidence is needed to confirm if these translate into clinical effects reflecting disease modification.

\section{Time to institutionalization}

There is limited and conflicting evidence that donepezil treatment has an effect on the patient-oriented outcome of delayed time to institutionalization (Table 10). The AD2000 RCT found no significant difference between the donepezil group and placebo group in institutionalization at 1 or 3 years (Courtney et al. 2004). However, the small number of patients remaining in this study at 3 years must be taken into account $(n=57$ and 60 in donepezil and placebo groups, respectively).

Lower level evidence (level 3) from two large studies supports a delay in or reduced risk of nursing home placement among patients treated with donepezil (Geldmacher et al. 2003; Beusterien et al. 2004), particularly those who complied well with their treatment regimen (Geldmacher et al. 2003; Table 10). In a smaller study, 135 pairs of patients with probable Alzheimer's disease were matched to compare those on AChEls (130 on donepezil) with untreated patients (Lopez et al. 2005). Within 2 years of study entry, $16 \%$ of untreated patients were in a nursing home, compared with $1 \%$ of treated patients (relative risk, $0.06 ; 95 \%$ confidence interval $0.008,0.48 ; P=0.001)$. This significant difference in nursing home admissions was maintained at 3 years (50 vs $11 \%, P<0.001)$. These results are supported by a systematic review which notes that, in observational studies, use of donepezil appeared to show a benefit on delayed time to nursing home placement (NICE 2005).

\section{Quality of life}

Evidence is divided on whether donepezil improves patients' quality of life (Table 11). The systematic reviews reported mixed results, with the most recent (conducted by the NICE Assessment Group) pointing to improvements, no change, and worsening quality of life in three RCTs, and the impact of the dose used for donepezil being unclear (NICE 2005). Only one open-label study was identified beyond those covered in the systematic reviews, and this study did not use a validated quality-of-life scale for dementia (Frölich et al. 2002). Instead, investigators were asked to answer the question, "How did therapy with donepezil influence the quality of life of the patient and/or his family over the observation period?", offering three possible outcomes: improved, unchanged, or worsened. After 3 months of treatment, quality of life was judged as "improved" in $70 \%$ of patients overall.

\section{Caregiver burden}

There is some evidence that donepezil lessens caregiver burden in terms of caring time spent each day (Table 11). However, only one systematic review mentions this aspect (Birks \& Harvey 2003), reporting that caregiver stress was assessed in one study, but the results were reported without any measure of precision. This review also highlights the results of an RCT, which showed significant benefit with donepezil treatment in comparison with placebo in time spent each day by the caregiver assisting with ADL.

Level 2 evidence from RCTs is conflicting (Courtney et al. 2004; Wimo et al. 2004). At 12 months, Wimo et al. (2004) reported a significant difference in caring time relative to baseline between 
Table 10 | Effects of donepezil on disease progression and time to institutionalization

\begin{tabular}{|c|c|c|c|c|c|c|c|}
\hline \multirow{2}{*}{$\begin{array}{l}\text { Level of } \\
\text { evidence }\end{array}$} & \multirow[t]{2}{*}{ Design } & \multirow{2}{*}{$\begin{array}{l}\text { Treatment, } \\
\text { dose, duration }\end{array}$} & \multicolumn{3}{|c|}{ Disease progression measurement } & \multirow{2}{*}{$\begin{array}{l}\text { Time to } \\
\text { institutionalization }\end{array}$} & \multirow[t]{2}{*}{ Reference } \\
\hline & & & rCBF & qEEG & Other & & \\
\hline 1 & $\begin{array}{l}\text { Systematic } \\
\text { review }\end{array}$ & $\mathrm{DPZ} \mathrm{Z}^{\mathrm{a}}$ & & & & $\begin{array}{l}\text { In observational studies, } \\
\text { DPZ appeared to show } \\
\text { benefit on delayed time } \\
\text { to NHP }\end{array}$ & NICE 2005 \\
\hline 2 & $\begin{array}{l}\text { MC, DB, } \\
\text { RCT }\end{array}$ & $\begin{array}{l}\text { DPZ } 5 \text { or } \\
10 \mathrm{mg} / \text { day } \\
(n=283) \text { or } P L \\
(n=283), \leq 3 \text { y }\end{array}$ & & & $\begin{array}{l}\text { NSD vs PL for progression } \\
\text { of disability or numbers of } \\
\text { deaths }\end{array}$ & $\begin{array}{l}\text { NSD vs PL (42 vs } 44 \% \\
\text { at } 3 y, P=0.4 \text { ) }\end{array}$ & $\begin{array}{l}\text { Courtney } \\
\text { et al. } 2004\end{array}$ \\
\hline 2 & $\begin{array}{l}\text { MC, DB, } \\
\text { RCT }\end{array}$ & $\begin{array}{l}\text { DPZ } 10 \mathrm{mg} / \text { day } \\
(\mathrm{n}=253), \text { vitamin } \mathrm{E} \\
(\mathrm{n}=257) \text {, or } \mathrm{PL} \\
(\mathrm{n}=259), 3 \mathrm{y}\end{array}$ & & & $\begin{array}{l}\mathrm{SD}(P=0.04) \text { in favor of } \\
\mathrm{DPZ} \text { vs } \mathrm{PL} \text { for disease } \\
\text { progression at } 12 \mathrm{mo} \\
\text { (16 vs } 38 \mathrm{pts} \text { ) but not } \\
\text { after } 3 \mathrm{y}\end{array}$ & & $\begin{array}{l}\text { Petersen } \\
\text { et al. } 2005\end{array}$ \\
\hline 2 & RCT & $\begin{array}{l}\text { DPZ } 5 \text { mg/day } \\
(n=15) \text { or } P L \\
(n=20), 12 \text { mo }\end{array}$ & $\begin{array}{l}\mathrm{SD} \text { vs } \mathrm{PL} \text { in } \\
\text { preservation of rCBF }\end{array}$ & & & & $\begin{array}{l}\text { Nakano et al. } \\
2001\end{array}$ \\
\hline 3 & $\begin{array}{l}\text { Retrospect- } \\
\text { ive, matched } \\
\text { control }\end{array}$ & $\begin{array}{l}\text { DPZ } 5 \text { or } \\
10 \mathrm{mg} / \text { day } \\
(\mathrm{n}=5423) ; \\
\text { untreated control } \\
(\mathrm{n}=5423), \mathrm{NR}\end{array}$ & & & $\begin{array}{l}\text { DPZ group had lower } \\
\text { mortality rate than control } \\
\text { (HRR 0.89; } 95 \% \mathrm{Cl} 0.83 \text {, } \\
0.95) \text {. With adjustment for } \\
\text { confounding variables, } \\
\text { HRR } 0.9 \text { (95\% Cl 0.84, } \\
0.96 \text { ) }\end{array}$ & & $\begin{array}{l}\text { Gasper et al. } \\
2005\end{array}$ \\
\hline 3 & $\begin{array}{l}\text { OL, } \\
\text { matched } \\
\text { control }\end{array}$ & $\begin{array}{l}\text { DPZ } 5 \mathrm{mg} / \text { day } \\
\text { for } 11 \pm 2.6 \text { mo } \\
(n=25) ; \text { untreated } \\
\text { control }(n=13)\end{array}$ & $\begin{array}{l}\text { In control group, SD } \\
\text { vs } B L \text { in rCBF } \\
\text { reduction. NSD in } \\
\text { DPZ group }\end{array}$ & & & & $\begin{array}{l}\text { Nobili et al. } \\
2002\end{array}$ \\
\hline 3 & $\begin{array}{l}\text { OL, } \\
\text { matched } \\
\text { control }\end{array}$ & $\begin{array}{l}\text { DPZ } 5 \mathrm{mg} / \text { day } \\
(\mathrm{n}=20) \text { for } 1 \mathrm{y} ; \\
\text { untreated control } \\
(\mathrm{n}=11)\end{array}$ & & $\begin{array}{l}\text { SD vs control in } \\
\text { MMSE }(P<0.01) \\
\text { and qEEG ratio } \\
(P<0.01)\end{array}$ & & & $\begin{array}{l}\text { Rodriguez } \\
\text { et al. } 2002\end{array}$ \\
\hline 3 & $\begin{array}{l}\text { OL, } \\
\text { matched } \\
\text { control }\end{array}$ & $\begin{array}{l}\text { DPZ, NR } \\
(n=130), \text { TAC, } \\
N R(n=22), \text { RIV, } \\
\text { NR }(n=6), \text { control } \\
(n=135) \text {, follow- } \\
\text { up at } 2 \text { and } 3 \text { y }\end{array}$ & & & & $\begin{array}{l}\text { At } 2 \text { y, NHP } 16 \% \text { in } \\
\text { control vs } 1 \% \text { in treated } \\
\text { group (relative risk, } 0.06 \text {; } \\
P=0.001) . \text { At } 3 \text { y, } 50 \text { vs } \\
11 \%(P<0.001)\end{array}$ & $\begin{array}{l}\text { Lopez et al. } \\
2005\end{array}$ \\
\hline 3 & $\begin{array}{l}\text { Retrospect- } \\
\text { ive analysis }\end{array}$ & $\begin{array}{l}\text { DPZ, NR } \\
(n=3864), \text { RIV, } \\
\text { NR }(n=1181), \\
\text { control }(n=517) \\
\text { from BL (April 1, } \\
\text { 2000) to NHP or } \\
\text { June 30, } 2002\end{array}$ & & & & $\begin{array}{l}4.4,3.7,11 \% \text { of DPZ, } \\
\text { RIV, control subjects had } \\
\text { an NHP. NSD in risk of } \\
\text { NHP between DPZ and } \\
\text { RIV }\end{array}$ & $\begin{array}{l}\text { Beusterien } \\
\text { et al. } 2004\end{array}$ \\
\hline
\end{tabular}




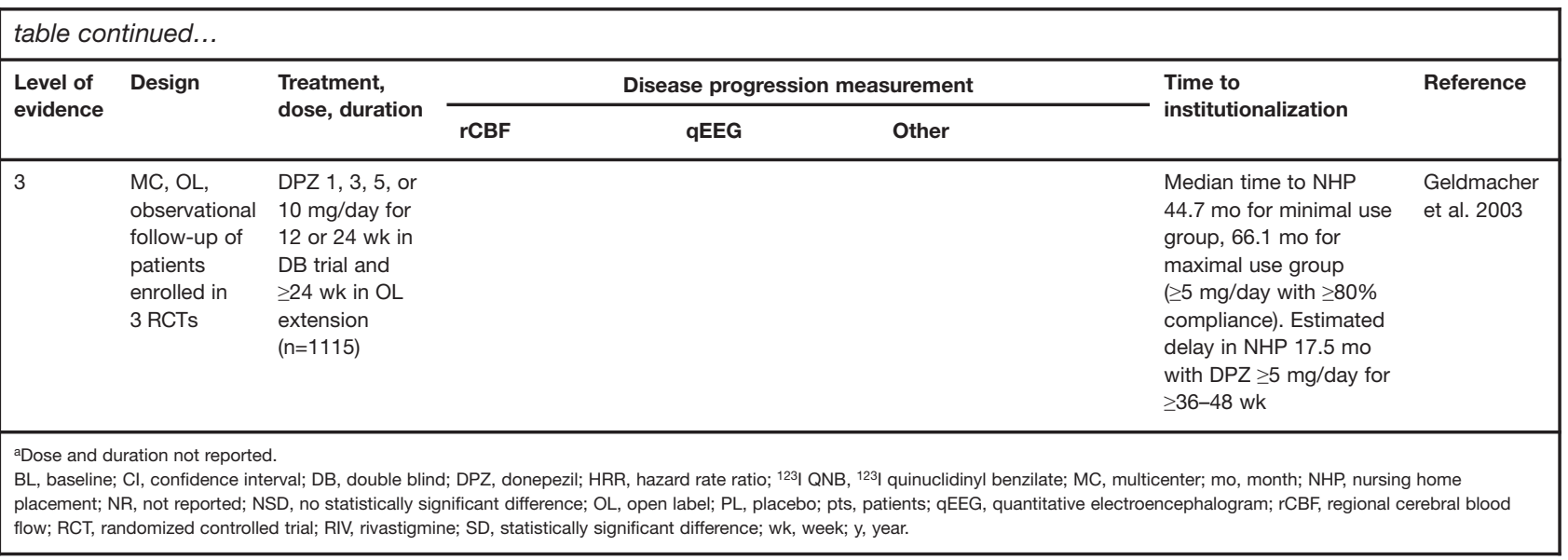

caregivers of donepezil-treated patients and caregivers of placebo-treated patients of $1.1 \mathrm{~h}$ per day $(P=0.03)$ (Wimo et al. 2004). In the AD2000 study, however, there were no significant differences between the donepezil and placebo groups in any of the caregiver parameters assessed (Courtney et al. 2004).

Further evidence suggesting a positive effect of donepezil on caregiver burden comes from an open-label study in which a self-administered, nationwide survey was used to match 274 caregivers of patients treated with donepezil to 274 caregivers of untreated patients (Fillit et al. 2000). There were significant differences between the groups in favor of donepezil on the total difficulty scale $(P=0.004)$, mainly due to differences in assisting with walking $(P \leq 0.001)$, providing emotional support $(P \leq 0.001)$, and managing behavioral problems $(P=0.05)$. However, there was no significant difference on the demand scale, which measured the frequency of engaging in caregiving activities.

\section{Tolerability}

Poor drug tolerability is a serious concern in patients with Alzheimer's disease because of their advanced age and the high prevalence of comorbid disease (Jackson et al. 2004). There is level 1 evidence that donepezil is well tolerated and that adverse events are usually cholinergic in nature (e.g. nausea, vomiting, and diarrhea) and generally mild and transient (Clegg et al. 2002; Wolfson et al. 2002; Birks \& Harvey 2003; Warner et al. 2004; Whitehead et al. 2004). Adverse events were recorded more often in patients receiving donepezil than in those on placebo, and there was an increased frequency with the higher dose of $10 \mathrm{mg} /$ day (Birks \& Harvey 2003; Whitehead et al. 2004; NICE 2005). Also, in the short term, more patients discontinued donepezil treatment on account of adverse events than in placebo groups. However, when treatment was longer than 12 weeks, there was no evidence of a difference in numbers of patients leaving the trials (Birks \& Harvey 2003).

A dose-dependent effect was confirmed in a meta analysis of individual patient data from 10 RCTs (Whitehead et al. 2004). In 821 patients treated with donepezil $5 \mathrm{mg} /$ day, only the incidence of diarrhea was significantly higher in the donepezil group in comparison with placebo (7 vs $4 \%, P<0.01$ ). Among patients treated with donepezil $10 \mathrm{mg} /$ day $(\mathrm{n}=662)$, nausea $(21 \%)$, diarrhea (16\%), headache (13\%), insomnia (12\%), vomiting (11\%), dizziness $(8 \%)$, and pain $(8 \%)$ (all $P<0.01)$, and rhinitis $(8 \%$, $P<0.05)$ had significantly higher incidences compared with placebo. However, the authors note that, of the adverse events that occurred in at least $5 \%$ of patients, only diarrhea, nausea, vomiting, and dizziness were considered related to study medication in a majority of patients in each treatment group. Also, most adverse events were mild, only occasionally moderate in intensity, and generally transient in nature.

In the larger open-label studies ( $\mathrm{n}>100)$, reported incidences of adverse events ranged widely, from 9.3 to $96 \%$ (Table 12). Gastrointestinal and psychiatric/neurologic adverse events were reported most frequently, and the frequency of discontinuations due to adverse events was less than $10 \%$ in most studies. In the two largest studies conducted, donepezil treatment was regarded as well tolerated, despite high concomitant medication use and extensive comorbidity among the patient groups (Hager et al. 2003; Relkin et al. 2003). However, there was inconsistency in incidences of adverse events; while Relkin et al. (2003) reported incidences in line with those in RCTs, Hager et al. (2003) reported considerably lower incidences. The latter authors suggest that this may be explained by the naturalistic nature of the postmarketing surveillance study, where the treating physician is likely to not ask for adverse events as specifically as in a controlled trial. Also in this study, most patients whose donepezil dose was increased to $10 \mathrm{mg}$ were able to tolerate the treatment as well as those who continued on the $5 \mathrm{mg}$ dose (Hager et al. 2003). In contrast, Relkin et al. (2003) found the occurrence of cholinergic-induced adverse events appeared to be directly related to the timing of dose increase from 5 to $10 \mathrm{mg} /$ day at 4 weeks (Relkin et al. 2003).

The tolerability profile of donepezil appears be qualitatively similar to that of rivastigmine and galantamine in terms of the nature of adverse events. However, in terms of relative frequency of adverse events, there is level 1 evidence that fewer people had at least one 


\section{Table 11 | Effects of donepezil on quality of life and caregiver burden}

\begin{tabular}{|c|c|c|c|c|c|}
\hline \multirow{2}{*}{$\begin{array}{l}\text { Level of } \\
\text { evidence }\end{array}$} & \multirow[t]{2}{*}{ Design } & \multirow{2}{*}{$\begin{array}{l}\text { Treatment, dose, } \\
\text { duration }\end{array}$} & \multicolumn{2}{|r|}{ Outcome } & \multirow[t]{2}{*}{ Reference } \\
\hline & & & Quality of life & Caregiver burden & \\
\hline 1 & Systematic review & $\mathrm{DPZ}$ & $\begin{array}{l}\text { Improvements, no change, and } \\
\text { worsening reported ( } 3 \text { trials) }\end{array}$ & & NICE 2005 \\
\hline 1 & Systematic review & $\begin{array}{l}\text { DPZ, NR, } 12 \text { or } \\
24 \text { wk }\end{array}$ & NSD in patient-rated quality of life & & $\begin{array}{l}\text { Warner et al. } \\
2004\end{array}$ \\
\hline \multirow[t]{2}{*}{1} & Systematic review & $\begin{array}{l}\text { DPZ } 5 \text { or } 10 \mathrm{mg} / \mathrm{day} \text {, } \\
12 \text { or } 24 \mathrm{wk}\end{array}$ & No evidence of benefit & $\begin{array}{l}\text { Carer stress assessed in } 1 \text { study but results reported } \\
\text { without any measure of precision }\end{array}$ & $\begin{array}{l}\text { Birks \& } \\
\text { Harvey } \\
2003^{\text {b }}\end{array}$ \\
\hline & & $\begin{array}{l}\text { DPZ } 10 \mathrm{mg} / \mathrm{day} \text {, } \\
24 \mathrm{wk}\end{array}$ & & $\begin{array}{l}\text { SD vs PL in time spent/day by carer assisting with } \\
\text { IADL and PSMS: MD }-81.9 \text { min }(P=0.02) \text { ( } 1 \text { study) }\end{array}$ & \\
\hline 1 & Systematic review & $\begin{array}{l}\text { DPZ } 5 \text { or } \\
10 \mathrm{mg} / \text { day, NR }\end{array}$ & $\begin{array}{l}\text { Of } 4 \text { RCTs, } 3 \text { showed NSD and } \\
1 \text { significant worsening vs PL }\end{array}$ & & $\begin{array}{l}\text { Clegg et al. } \\
2002\end{array}$ \\
\hline 2 & $\mathrm{MC}, \mathrm{DB}, \mathrm{RCT}$ & $\begin{array}{l}\text { DPZ 5-10 mg/day } \\
(\mathrm{n}=96) \text { or } \mathrm{PL}(\mathrm{n}=94) \\
12 \mathrm{mo}\end{array}$ & & $\begin{array}{l}\text { Increase in caring time from BL (assessed by RUD) } \\
\text { significantly lower in DPZ vs PL group ( } 42.6 \text { vs } 106.8 \\
\text { min, } P=0.03 \text { ) at } 12 \text { mo }\end{array}$ & $\begin{array}{l}\text { Wimo et al. } \\
2004\end{array}$ \\
\hline 2 & $\mathrm{MC}, \mathrm{DB}, \mathrm{RCT}$ & $\begin{array}{l}\text { DPZ } 5 \text { or } 10 \mathrm{mg} / \text { day } \\
(\mathrm{n}=283) \text { or } \mathrm{PL} \\
(\mathrm{n}=283), \leq 3 \mathrm{y}\end{array}$ & & $\begin{array}{l}\text { After } 2 \text { y, NSD vs PL for carer psychologic morbidity, } \\
\text { active daily time input, passive care time, and unpaid } \\
\text { caregiver time }\end{array}$ & $\begin{array}{l}\text { Courtney } \\
\text { et al. } 2004\end{array}$ \\
\hline 3 & OL & $\begin{array}{l}\text { DPZ } 5 \text { or } 10 \mathrm{mg} / \text { day } \\
(\mathrm{n}=913), 3 \mathrm{mo}\end{array}$ & Improvement in $70 \%$ of patients & & $\begin{array}{l}\text { Frölich et al. } \\
2002\end{array}$ \\
\hline 3 & $\begin{array}{l}\text { Survey of } \\
\text { Alzheimer patient } \\
\text { caregivers, } \\
\text { matched control }\end{array}$ & $\begin{array}{l}\text { DPZ, NR }(n=274) \text { or } \\
\text { untreated control } \\
(n=274), \geq 9 \text { mo }\end{array}$ & & $\begin{array}{l}\text { SD in favor of DPZ between } 2 \text { groups of caregivers } \\
\text { on total difficulty scale }(P=0.004) \text {. NSD on demand } \\
\text { scale }\end{array}$ & $\begin{array}{l}\text { Fillit et al. } \\
2000\end{array}$ \\
\hline $\begin{array}{l}{ }^{\text {aD }} \text { ose and d } \\
\text { bAssessmen } \\
\text { BL, baseline } \\
\text { statistically } \\
\text { SD, statistic }\end{array}$ & $\begin{array}{l}\text { ation not reported. } \\
\text { cluded patients with } \\
\mathrm{B} \text {, double blind; DPZ, } \\
\text { nificant difference; OL } \\
\text { significant difference }\end{array}$ & $\begin{array}{l}\text { onepezil; IADL, Instrumer } \\
\text { pen label; PL, placebo; P } \\
\text { vk, week; y, year. }\end{array}$ & $\begin{array}{l}\text { nentia due to Alzheimer's disease. } \\
\text { Activities of Daily Living; MC, multicente } \\
\text { MS, Physical Self-Maintenance Scale; RC }\end{array}$ & $\begin{array}{l}\text { MD, mean difference; min, minute; mo, month; NR, not reported; } \\
\text { randomized controlled trial; RUD, Resource Utilization in Dement }\end{array}$ & $\begin{array}{l}\text { NSD, no } \\
\text { questionnaire; }\end{array}$ \\
\hline
\end{tabular}

adverse event with donepezil compared with rivastigmine, although the difference was not significant ( 43 vs $58 \%$, relative risk 0.74 ) (Warner et al. 2004). The between-group difference in number of patients discontinuing treatment, however, was significant in favor of donepezil (11 vs $31 \%$, relative risk 0.35). Similar rates of adverse events, severe adverse events, and adverse events leading to withdrawal were reported in galantamine- and donepezil-treated patients (Warner et al. 2004). This is supported by level 3 evidence from 6- and 9-month open-label trials (Aguglia et al. 2004; Mossello et al. 2004). In one study, patients were administered donepezil $(n=256)$, rivastigmine $(n=132)$, or galantamine $(n=19)$ (Mossello et al. 2004). The percentage of patients that discontinued treatment was significantly lower in the donepezil group (3\%) than in the rivastigmine $(17 \%, P<0.01)$ or galantamine groups $(21 \%, P<0.01)$, although the number of patients in the galantamine group was low. In another study of patients treated with donepezil $(n=70)$, rivastigmine $(n=121)$, or galantamine $(n=51)$, the most common adverse events were gastrointestinal and the frequency of these events were similar in all treatment groups ( $<6 \%$ for each event) (Aguglia et al. 2004).

Thus, there is strong evidence that donepezil is well tolerated and that the most common adverse events can be predicted from its cholinergic mechanism of action. Also, the frequency of these adverse events appears to be dose related. There is some evidence that the incidence of adverse events is lower outside of the clinical trial setting, although a wide variation in percentages was observed in open-label studies.

\section{Economic evidence}

Alzheimer's disease is a chronic and progressive condition with no cure and presents a variety of challenges for patients and their families, caregivers, and healthcare providers, as discussed in the Disease overview section. Evaluation of the economic impact of the disease requires consideration of three broad categories of costs: direct, indirect, and intangible costs (Leung et al. 2003; Table 13). However, inconsistent assessment of these variables and geographic differences in care patterns have produced highly variable cost-of-illness estimates. For example, in an assessment of 23 economic studies, estimations of annual costs per Alzheimer's disease patient ranged from \$US5799 to \$US75 490 (Leung et al. 2003). These estimates were affected mainly by the inclusion or exclusion of costs associated with long-term care, unpaid caregiving, and institutionalization. 
Table 12 | Tolerability of donepezil reported in open-label trials that included more than 100 patients (level 3 evidence)

\begin{tabular}{|c|c|c|c|c|c|}
\hline $\begin{array}{l}\text { Number of patients, } \\
\text { duration of study }\end{array}$ & Incidence of AEs & Most common AEs & $\begin{array}{l}\text { Discontinuation } \\
\text { due to AEs }\end{array}$ & Other & Reference \\
\hline $237,24 \mathrm{wk}$ & $\begin{array}{l}73 \% ; \text { most mild to } \\
\text { moderate and transient }\end{array}$ & $\begin{array}{l}\text { Agitation }(25 \%) \text {, fatigue } \\
(15 \%) \text {, headache }(14 \%) \text {, } \\
\text { insomnia }(13 \%) \text {, } \\
\text { confusion }(12 \%)\end{array}$ & $\begin{array}{l}12 \% . \text { Most frequently } \\
\text { cardiovascular events, } \\
\text { agitation, nausea or } \\
\text { vomiting, muscle } \\
\text { cramps, urinary } \\
\text { incontinence }\end{array}$ & $\begin{array}{l}\text { Global tolerability rated as very } \\
\text { good } / \text { good in } 81 \% \text { of patients }\end{array}$ & $\begin{array}{l}\text { Froelich et al. } \\
2004\end{array}$ \\
\hline 256, 9 mo & NR & $\begin{array}{l}\text { No major drug-related } \\
\text { AEs observed. No detail } \\
\text { given }\end{array}$ & $\begin{array}{l}8 \text { patients }(3 \%) \text { : } \\
\text { behavioral ( } 4 \text { patients) } \\
\text { gastrointestinal }(3) \text {, } \\
\text { pulmonary (1) }\end{array}$ & $\begin{array}{l}\text { SD between DPZ and RIV ( } 3 \text { vs } 17 \% \text {, } \\
P<0.01 \text { ), DPZ and GAL ( } 3 \text { vs } 21 \% \text {, } \\
P<0.01 \text { ) in percentage discontinuation }\end{array}$ & $\begin{array}{l}\text { Mossello } \\
\text { et al. } 2004\end{array}$ \\
\hline 2094, 3 mo & $12.2 \%$ & $\begin{array}{l}\text { Nausea }(2.2 \%) \text {, diarrhea } \\
(1.4 \%) \text {, trembling inside } \\
(1.4 \%) \text {, vomiting }(1.1 \%)\end{array}$ & $\begin{array}{l}6.1 \% \text { (55.4\% of } \\
\text { discontinuations) }\end{array}$ & $\begin{array}{l}\text { Global tolerability judged by investigators } \\
\text { as "very good" or "good" in } 91.3 \% \text { of } \\
\text { patients assessed ( } n=1989) \text {. SAEs } \\
\text { reported in } 46 \text { patients }(2.2 \%) \text {; } \\
10 \text { considered possibly/probably related } \\
\text { to DPZ treatment }\end{array}$ & $\begin{array}{l}\text { Hager et al. } \\
2003^{a}\end{array}$ \\
\hline $1035,12 \mathrm{wk}$ & $70 \% ; 64 \%$ mild & $\begin{array}{l}\text { Diarrhea (10\%), nausea } \\
(9 \%)\end{array}$ & $\begin{array}{l}6.2 \% \text {. Most common } \\
\text { causes: agitation, } \\
\text { confusion, dizziness, } \\
\text { headache, nausea ( } 6 \\
\text { patients each; } 0.6 \% \\
\text { each) }\end{array}$ & $\begin{array}{l}\text { SAEs reported for } 94 \text { patients }(9 \%) \text {; } \\
34(3 \%) \text { considered related to DPZ }\end{array}$ & $\begin{array}{l}\text { Relkin et al. } \\
2003\end{array}$ \\
\hline $200,24 \mathrm{wk}$ & $69 \%$ & $\begin{array}{l}\text { Nausea }(8 \%) \text {, } \\
\text { depression }(6 \%) \text {, } \\
\text { headache }(6 \%) \text {, } \\
\text { abdominal pain }(5 \%)\end{array}$ & $8.1 \%$ & $\begin{array}{l}\text { SAEs reported in } 18 \text { patients }(9.1 \%) \text {; } \\
\text { none attributable to DPZ }\end{array}$ & $\begin{array}{l}\text { Santens \& } \\
\text { Ventura } 2003\end{array}$ \\
\hline 913, 3 mo & $9.3 \%$ & $\begin{array}{l}\text { Nausea }(2.4 \%) \text {, } \\
\text { restlessness/agitation } \\
(1.4 \%) \text {, sleep } \\
\text { disturbances }(1.3 \%) \text {, } \\
\text { diarrhea }(1.3 \%), \\
\text { vomiting }(1.1 \%)\end{array}$ & $3.5 \%$ & SAEs reported in 14 patients $(1.5 \%)$ & $\begin{array}{l}\text { Frölich et al. } \\
2002\end{array}$ \\
\hline $108,12 \mathrm{mo}$ & $96 \%$ & $\begin{array}{l}\text { Pain ( } 27 \text { patients), } \\
\text { diarrhea (24), nausea } \\
\text { (23), dizziness (20), } \\
\text { headache (19), dyspepsia } \\
\text { (15), influenza-like } \\
\text { symptoms (15) }\end{array}$ & $\begin{array}{l}10 \text { patients: anxiety (2), } \\
\text { weight loss (2), diarrhea } \\
(1), \text { pacing (1), transient } \\
\text { ischemic attack (1), } \\
\text { confusion (1), agitated } \\
\text { depression (1), foot } \\
\text { pain (1) }\end{array}$ & $\begin{array}{l}22 \text { SAEs in } 16 \text { patients; none had clear } \\
\text { relation to DPZ }\end{array}$ & $\begin{array}{l}\text { Rockwood } \\
\text { et al. } 2002\end{array}$ \\
\hline
\end{tabular}

ancluded patients with severe Alzheimer's disease.

AE, adverse event; DPZ, donepezil; GAL, galantamine; mo, month; NR, not reported; RIV, rivastigmine; SAE, serious adverse event; SD statistically significant difference; wk, week.

Most of the economic analyses performed with donepezil have been modeling studies (Jönsson et al. 1999; Neumann et al. 1999; O'Brien et al. 1999; Ikeda et al. 2002; Fagnani et al. 2004). However, a review of AChEl modeling studies concluded that, because of methodologic considerations, their validity is difficult to judge (Wimo 2004). There are few publications of empiric economic data from RCTs of AChEls (Wimo 2004) and only two prospective studies were identified that examined the economic impact of donepezil treatment in patients with mild to moderate Alzheimer's disease (Courtney et al. 2004; Wimo et al. 2003b). One evaluation was performed as an adjunct to a 1-year, placebo- controlled clinical trial of donepezil (Wimo et al. 2003b). This economic "piggyback" evaluation was regarded as a reasonable approach, although the authors acknowledge that dedicated large-scale and long-term economic studies should be performed with adequate powering for economic variables. The AD2000 study also incorporated an economic evaluation (Courtney et al. 2004). However, as mentioned previously, the design and conclusions of this 3-year study have been criticized due to recruitment of only one fifth of the intended number of patients and high discontinuation rates at the end of the first and second years (Akintade et al. 2004; Holmes et al. 2004a). 
Table 13 | Major direct, indirect, and intangible costs associated with Alzheimer's disease (reproduced with permission from Leung et al. Dement Geriatr Cogn Disord. 2003;15:34-43. S. Karger AG, Basel)

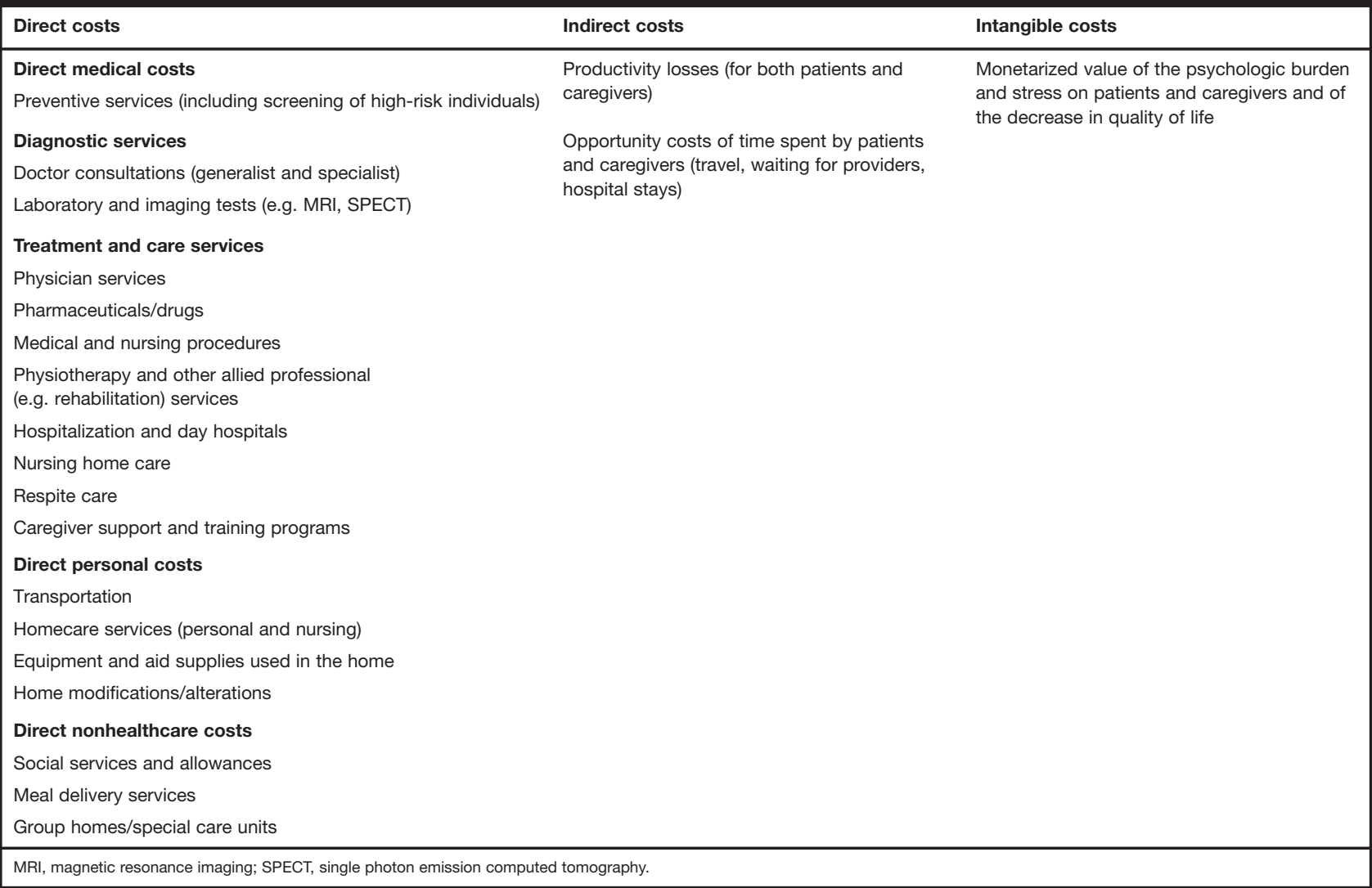

Therefore, there are limited economic data with donepezil in mild to moderate Alzheimer's disease. Further limitations can be identified when the available evidence is assessed in the context of two common observations that underlie most Alzheimer's disease cost-of-illness estimates (Leung et al. 2003):

1. the costs of informal, unpaid caregiver time make up an unusually large share of total costs (40-70\%) compared with other diseases

\section{2. there is a strong correlation between disease severity or} functional impairment and the associated costs of care.

Level 1 evidence suggests there have been few quantitative assessments of the contribution of unpaid caregiver time to the overall cost of donepezil treatment (Clegg et al. 2002; Wolfson et al. 2002; Leung et al. 2003; Wimo 2004; NICE 2005). This is an important observation as, following the introduction of drug regimens, cost burdens may be shifted from institutional to home care, resulting in savings to society as a whole (Leung et al. 2003).

There is level 2 evidence that donepezil is cost effective when caregiver costs are considered (Wimo et al. 2003b). In a 1-year, double-blind, randomized study, patients with mild to moderate
Alzheimer's disease received either donepezil ( $\mathrm{n}=142 ; 5 \mathrm{mg} /$ day for 28 days then $10 \mathrm{mg} /$ day according to the clinician's judgment) or placebo $(n=144)$. Mean annual patient-related healthcare costs were \$US16 438 per patient for the donepezil group and \$US16 147 in the placebo group. When caregiver costs (time- and healthcare-related) were included, mean annual costs increased to \$US24 969 per patient in the donepezil group and \$US26 066 in the placebo group. The total saving associated with donepezil treatment was \$US1097 per patient (95\% confidence interval $-5246,3053 ; P=0.6$ ), leading the authors to conclude that donepezil treatment was associated with no increase in cost to society compared with placebo treatment over 1 year. It is also noteworthy that caregiver time-related costs represented approximately one third of the total cost in each treatment group, emphasizing the importance of including costs of informal care in economic evaluations of mild to moderate Alzheimer's disease.

A modeling study of French patients with mild to moderate Alzheimer's disease provides further evidence (level 3) of the importance of including unpaid caregiver time in cost-effectiveness assessments (Fagnani et al. 2004). Costs considered in the economic model were net societal costs associated with paid and unpaid assistance, general medical consumption, and institutional care. Over a 3-year period, total net costs of caring for untreated 


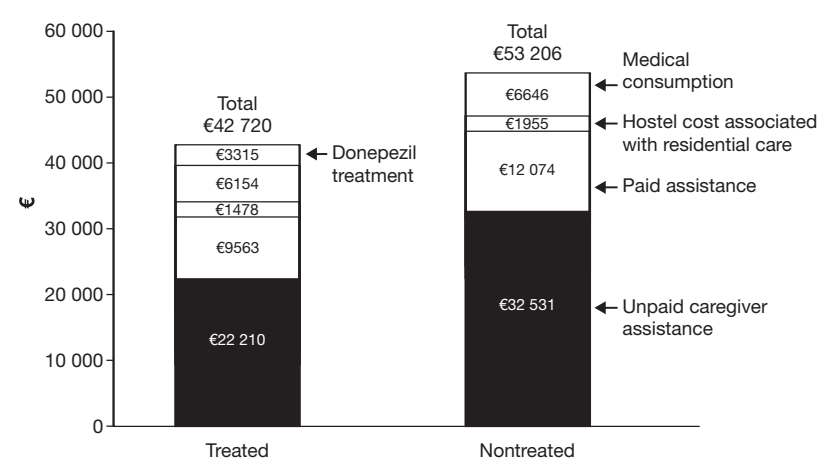

Fig. 2 | Net cost of care per Alzheimer's disease patient over 3 years (reproduced with permission from Fagnani et al. Dement Geriatr Cogn Disord. 2004;17:5-13. S. Karger AG, Basel)

patients were $€ 53206$ compared with $€ 42720$ for a patient treated with donepezil, representing an annual cost saving of approximately $€ 3500$ per patient (Fig. 2). The cost savings were mainly due to savings in unpaid caregiver time, which, apart from patient institutionalization, represented the most costly component of total care in this study but had no direct budgetary impact.

Correlation between the progression of Alzheimer's disease and increased costs of care means it is important to assess the longterm economic benefits of donepezil treatment. However, as mentioned previously, most economic studies have been based on projections and modeling rather than empiric observations from RCTs with an adequate follow-up period (Leung et al. 2003; Wimo 2004). Also, inconsistent methodologies make it difficult to compare study results. This is likely to account for the differences in study conclusions highlighted in level 1 evidence (Clegg et al. 2002; Wolfson et al. 2002; Leung et al. 2003; NICE 2005). Leung et al. (2003) identified five cost-effectiveness studies, of which three were cost saving, while two showed that donepezil treatment carried a cost (Leung et al. 2003). Another systematic review found seven studies, three of which demonstrated cost saving, two indicated cost neutrality, and a further two that showed an incremental cost with donepezil (Wolfson et al. 2002).

In an assessment of donepezil, rivastigmine, and galantamine, Clegg et al. (2002) concluded that cost effectiveness was uncertain and the impact on different care sectors had been inadequately investigated. Five donepezil studies were identified, which produced a very wide range of estimates. Two reported cost savings of £2011 to £2415 per year in nonsevere states for all cases. Another study estimated costs of $£ 1210$ and $£ 7048$ per year in nonsevere states for mild and moderate cases, respectively. A further study estimated costs of $£ 6054$ and $£ 49476$ per quality-adjusted life-year (QALY) for mild and moderate cases, respectively, and the fifth did not report a base case, so was not considered by the authors. Overall, the cost estimates for donepezil in Alzheimer's disease were not considered to be robust or generalizable.
The NICE Assessment Group identified 11 studies, five of which indicated cost saving for donepezil treatment (NICE 2005). One study, based on drug costs alone, estimated a cost per QALY gained (CQG) for the $5 \mathrm{mg} /$ day dose of $£ 21000$ (2-year model) to $£ 86000$ (10-year model) for a gain of 0.08 QALYs per person. The NICE Assessment Group also used their own model to estimate cost effectiveness of AChEls plus usual care versus usual care alone in a UK context from the perspective of a third-party payer. Cohorts of 1000 patients with mild to moderate Alzheimer's disease were modeled in a Markov disease progression model. The difference between the AChEl plus usual care and usual care groups in time spent in full-time care over 5 years ranged from 1.43 to 1.6 years, and QALYs gained ranged from 0.042 to 0.048 . The resulting base case CQG was $£ 94000$ for donepezil $10 \mathrm{mg} /$ day.

The NICE Assessment Group concluded that the AChEls are outside the range of cost effectiveness that might be considered appropriate for the UK NHS (NICE 2005). However, when the data were reevaluated, the cost effectiveness of donepezil was considered sufficiently acceptable to allow its prescription for Alzheimer's disease of moderate severity (NICE 2006). Concerns with the original NICE analysis had been raised, particularly in the use of CQG (Alzheimer's Society 2005; DoH 2005; RCP 2005). Weaknesses have been identified with this methodology in modeling disease progression, obtaining good quality information on costs for patients treated in the community, and sensitivity to small changes in estimated incremental costs. Also, the UK government's Department of Health (DoH) highlighted the need to compare the CQG of AChEls with that of nondrug interventions for cognition, behavior, ADLs, and caregiver burden. The DoH also notes that withdrawal of AChEls may lead to an increase in the prescribing of more harmful medications, such as antipsychotics, which should be considered in an assessment of costs (DoH 2005). Criticism has also been made of the exclusion of benefits to caregivers, in terms of quality of life, cost, time spent caring or impact on their health, and the restricted focus on utility for the individual recipient of the intervention (Alzheimer's Society 2005; DoH 2005; RCP 2005).

There have also been concerns regarding the methodology of the AD2000 study, as outlined previously (Akintade et al. 2004; Holmes et al. 2004a). This should be considered when assessing level 2 evidence from this trial, which indicated that donepezil was not cost effective, mainly because of no apparent benefits in delaying disease progression or time to institutionalization (Courtney et al. 2004). There was also no significant difference between the donepezil and placebo groups in mean annual cost per patient resident in the community for 11 formal health and social services ( $£ 2842$ vs $£ 2344, P=0.16$ ). Informal care was not costed because there were no significant differences in active and passive caregiver daily time input.

In contrast, there is level 3 evidence from a matched case-control study, which also did not include informal care costs, supporting the cost effectiveness of donepezil (Hill et al. 2002). Costs for 204 donepezil-treated patients were compared with a group of 204 untreated patients, controlling for age, gender, pharmacy 
benefits, comorbid conditions, and complications of dementia. Annual costs for medical services and prescription drugs were significantly lower for the treatment group (difference \$US3891, $P=0.016)$. This difference was largely attributable to significantly lower costs for inpatient hospital $(P=0.025)$ and skilled nursing facility services $(P=0.0001)$. Similarly, a retrospective analysis of patients with early-stage Alzheimer's disease found that annual healthcare costs were \$US2408 lower for 428 patients treated with an AChEl (one patient received tacrine, remainder donepezil) than for patients not receiving therapy (Fillit et al. 2002). Another case-control study conducted by the same research group included data from 229 patients treated with donepezil and 458 untreated patients (control group) (Lu et al. 2005). The mean cost of medical services per year in the donepezil group was $\$$ US2500 less than in the control group $(P=0.024)$. Lower medical costs in the donepezil group were largely attributable to the lower costs of services performed in the hospital $(P<0.004)$ and postacute skilled nursing facility $(P<0.001)$. Patients receiving donepezil also had shorter mean lengths of stay in the hospital ( 3 vs 5.4 days, $P<0.008$ ) but a higher mean number of physician's office visits ( 10.9 vs $7.9, P<0.001)$.

Thus, there are clearly many factors to be taken into account when assessing the cost effectiveness of any intervention in Alzheimer's disease. There is some evidence that treatment with donepezil is cost effective when unpaid caregiver time is considered, which is representative of the real-life situation for most patients. However, the existing evidence for donepezil is conflicting and, because of methodologic considerations, the validity of much of the available data is difficult to judge. RCTs with long-term follow-up are required to confirm the cost effectiveness of donepezil, taking into account multiple factors to calculate utility for both patients and caregivers.

\section{Resource utilization}

Alzheimer's disease is associated with significant resource utilization resulting from the direct and indirect costs of caring by family and friends as well as the costs of medical and institutional care (see The burden of illness section). In terms of drug treatment, expenditure on AChEls is expected to increase. For example, in the UK, the NICE Assessment Group reported that NHS expenditure on AChEls in the financial year 2003-2004 was approximately £48 million (NICE 2005). Based on 2001-2004 trends, this expenditure was expected to increase to at least $£ 70$ million in 2005-2006.

However, as discussed in the Economic evidence section, cost of drug treatment is one of many different elements that must be considered to gain an accurate picture of resource utilization in Alzheimer's disease. Table 13 lists the major direct, indirect, and intangible costs associated with Alzheimer's disease (Leung et al. 2003). Direct medical costs include costs or savings directly related to the interventions for Alzheimer's disease, costs induced or averted as a result of the intervention or information provided by it, costs required to manage adverse events or complications caused by the intervention, and all additional healthcare resources needed to treat conditions that occur during added years of life expectancy. Direct personal costs include transportation expenses to and from care facilities, costs of providing services in the home and community, and of support services for recuperation, rehabilitation, and coping with Alzheimer's disease. Direct nonhealthcare costs or savings are met by facilities such as welfare, housing, and education. Indirect costs and savings include changes in the productive use of time by patients and others. Intangible costs of illness provide a measure of the psychologic burden and stress on patients, families, and caregivers, and of any improvements in quality of life.

Any cost savings associated with AChEl treatment are likely to result mainly from delayed disease progression and delayed institutionalization, reduced hospital, emergency, and home care costs, reduced burden on unpaid caregivers, and improved quality of life. Estimates of resource utilization are included in many studies of donepezil, but are usually not readily identifiable when not included as primary outcomes. In general, however, there is some evidence, mainly from open-label trials, to suggest that donepezil treatment delays disease progression and time to institutionalization. There is also some evidence to suggest donepezil may lessen caregiver burden, particularly in terms of caring time. However, there is no strong evidence to suggest that donepezil improves patients' quality of life, with mixed results reported. Although there is therefore some evidence of benefit from donepezil on the major determinants of resource utilization, assessment of all areas points to the need for more robust data to confirm its impact.

\section{Patient group/population}

There is evidence to support the indication of donepezil for the symptomatic treatment of mild to moderate Alzheimer's disease, especially in terms of global outcomes, cognition, and function. There is no strong evidence of efficacy in particular subpopulations of patients with mild to moderate symptoms. There is evidence of efficacy in the treatment of mild cognitive impairment (Salloway et al. 2004; Petersen et al. 2005) and severe Alzheimer's disease (Gauthier et al. 2002; Birks \& Harvey 2003; Hager et al. 2003; Feldman et al. 2004). Although some of the patient entry criteria scores in these studies overlap with those of patients with mild to moderate Alzheimer's disease, donepezil is not indicated in these patient populations at this time. The manufacturer has filed with the Food and Drug Administration for approval in the severe Alzheimer's disease indication (Anon. 2005b).

\section{Dosage, administration, and formulations}

Donepezil (Aricept) is indicated for the symptomatic treatment of mild to moderate Alzheimer's disease. It is available as round, filmcoated tablets each containing donepezil hydrochloride 5 or $10 \mathrm{mg}$. It is also available as an orally disintegrating tablet formulation.

The recommended dose of donepezil is 5 or $10 \mathrm{mg}$ once daily. Although not unequivocally proven in clinical trials, there is some evidence to suggest that a daily donepezil dose of $10 \mathrm{mg}$ may provide additional benefit in some patients compared with a daily dose of $5 \mathrm{mg}$ (Birks \& Harvey 2003; Whitehead et al. 2004). 
However, a decision to increase the dose of donepezil is based on prescriber and patient preference and should not be made until the patient has been on a daily dose of $5 \mathrm{mg}$ for $4-6$ weeks. In comparison with titration over 1 week, titration over 4-6 weeks appears to reduce the frequency of adverse events (Anon. 2005a). Donepezil should be taken in the evening, just before retiring, and may be taken with or without food (Anon. 2005a).

\section{Clinical value}

The evidence summary table at the beginning of this article summarizes the clinical evidence for the impact of donepezil on clinical and economic outcome measures. There is evidence that donepezil has efficacy against the three major domains of Alzheimer's disease symptoms, namely functional ability, behavior, and cognition. The strongest evidence is for improvement or less deterioration in global outcomes and cognition in the short to medium term. There is some evidence that improved global outcomes are maintained in the long term and clear evidence to support the long-term maintenance of cognitive benefits. Also, there is strong evidence of maintained function in the long term. Therefore, there is substantial evidence to suggest that donepezil treatment stabilizes cognitive and functional symptoms in the long term. Although some level 1 and 2 evidence supports improved or limited deterioration in behavior or mood in the short to medium term, no evidence exists for a long-term effect against this particular symptom.

Despite evidence that donepezil has an effect on a patient's overall or global health state and major symptoms of Alzheimer's disease, studies to date have provided inconsistent results concerning effect on patients' quality of life. This may reflect the difficulty of assessing quality of life in individuals with cognitive disabilities (Andersen et al. 2004) and points to the need for more studies on this aspect of Alzheimer's disease (Alzheimer's Society 2005).

There are few long-term data on disease progression, with most of the evidence coming from studies of disease-oriented rather than patient-oriented outcomes. Donepezil has some effect on markers of brain function and volume, and further evaluation of a neuroprotective effect is required. One trial (level 2 evidence) provides some evidence of an effect on progression from mild cognitive impairment to Alzheimer's disease, with reduced likelihood of such progression at 12 months but not at 3 years. There is limited and conflicting evidence to suggest that longterm donepezil treatment delays time to institutionalization.

There is strong evidence that donepezil is well tolerated and the most common adverse events are predictable. There is evidence from observational studies that this good tolerability profile is maintained or may even be improved in community-based clinical practice.

Evidence that donepezil may lessen caregiver burden has some relevance to economic assessments of donepezil, which require many factors to be taken into account including costs met by unpaid caregivers. Consideration of the acquisition and administration costs of donepezil in isolation reveals no cost- saving benefit. However, some evidence supports the cost effectiveness of donepezil when unpaid caregiver costs are included to reflect community-based clinical practice. Furthermore, preliminary guidance from NICE states that the cost effectiveness of donepezil is sufficiently acceptable to allow its prescription in England and Wales for Alzheimer's disease of moderate severity (NICE 2006).

In summary, AChEls are the only agents recommended for the treatment of cognitive decline in patients with mild to moderate Alzheimer's disease. There is strong evidence that donepezil is more effective than placebo and is well tolerated in improving the major symptoms of this disease. Improvements are usually modest, although stabilization of cognitive and functional symptoms with donepezil can also be considered an important clinical outcome. There is some evidence that donepezil lessens caregiver burden, a significant outcome given the long-term and progressive nature of the disease. This suggests that alleviation of symptoms with donepezil may reduce the burden for patients and their caregivers, especially when compared with no treatment. Also, there is some evidence that donepezil may be cost saving, especially when unpaid caregiver costs are included. More data are required from RCTs with long-term follow-up to confirm its cost effectiveness and the impact of donepezil treatment on quality of life, disease progression, and time to institutionalization.

\section{References}

Aguglia E, Onor ML, Saina M, Maso E. An open-label, comparative study of rivastigmine, donepezil and galantamine in a real-world setting. Curr Med Res Opin. 2004;20:1747-1752.

Akintade L, Zaiac M, leni JR, McRae T. AD2000: design and conclusions. Lancet. 2004;364:1214.

Alzheimer's Association. Medicare and Medicaid costs for people with Alzheimer's disease. Chicago, IL: Alzheimer's Association; April, 2001. Available at: http://www.alz.org/media/newsreleases/alzreport.pdf (accessed September 29, 2005).

Alzheimer's Association. Alzheimer's disease statistics. Chicago, IL: Alzheimer's Association; April 2004. Available at:

http://search.alz.org/resources/factsheets/fsalzheimerstats.pdf (accessed September 29, 2005).

Alzheimer's Society. Policy positions - carer support. London: Alzheimer's Society; July 2004. Available at:

http://www.alzheimers.org.uk/news_and_campaigns/policy_watch/carersupport. htm (accessed September 29, 2005).

Alzheimer's Society. News and campaigns. Drugs for the treatment of Alzheimer's disease. A summary of the Alzheimer's Society's response to draft guidance from NICE (the National Institute for Clinical Excellence). London: Alzheimer's Society; May 2005. Available at:

http://www.alzheimers.org.uk/news_and_campaigns/pdf/summary_nicerespons e_drugsforalzheimers.pdf (accessed September 29, 2005).

Andersen CK, Wittrup-Jensen KU, Lolk A, Andersen K, Kragh-Sørensen P. Ability to perform activities of daily living is the main factor affecting quality of life in patients with dementia. Health Qual Life Outcomes. 2004;2:52.

Anon. Aricept Prescribing Information. Available at: http://www.aricept.com/pi/aricept_pi.htm (accessed September 29, 2005a).

Anon. Eisai submits to FDA for Aricept ${ }^{\circledR}$ for treatment of severe Alzheimer's disease. Ridgefield Park, NJ: Eisai Co., Ltd. press release; September 1, 2005b. Available at: http://www.eisai.com/view_press_release.asp?ID=147\&press=125 (accessed September 29, 2005).

Anon. Exelon Prescribing Information. Available at: http://www.exelon.com/hcp/tools/prescribing.jsp (accessed September 29, 2005c). 
Anon. Namenda Prescribing Information. Available at: http://www.frx.com/pi/namenda_pi.pdf (accessed September 29, 2005d).

Anon. Reminyl Prescribing Information. Available at:

http://www.janssen.com/html/jan/pd_our_products.xml?article=prescribinginfo_ reminyl.jspf (accessed September 29, 2005e).

APA (American Psychiatric Association). Practice guideline for the treatment of patients with Alzheimer's disease and other dementias of late life. Am J Psychiatry. 1997;154(5 Suppl.):1-39.

Beusterien KM, Thomas SK, Gause D, Kimel M, Arcona S, Mirski D. Impact of rivastigmine use on the risk of nursing home placement in a US sample. CNS Drugs. 2004;18:1143-1148.

Birks JS, Harvey R. Donepezil for dementia due to Alzheimer's disease. Cochrane Database Syst Rev. 2003;(3):CD001190.

Birks J, Grimley Evans J, lakovidou V, Tsolaki M. Rivastigmine for Alzheimer's disease. Cochrane Database Syst Rev. 2000;(4):CD001191.

Blasko I, Bodner T, Knaus G, et al. Efficacy of donepezil treatment in Alzheimer patients with and without subcortical vascular lesions. Pharmacology. 2004;72:1-5.

Burns A, Rossor M, Hecker J, et al. The effects of donepezil in Alzheimer's disease - results from a multinational trial. Dement Geriatr Cogn Disord. 1999;10:237-244.

California Workgroup on Alzheimer's Disease Management. Guidelines for Alzheimer's disease management. Los Angeles, CA: Alzheimer's Association of Los Angeles, Riverside and San Bernardino Counties; Jan 1, 2002. Available at: http://www.alzla.org/medical (accessed September 29, 2005).

Casadesus G, Smith MA, Zhu X, et al. Alzheimer disease: evidence for a central pathogenic role of iron-mediated reactive oxygen species. $J$ Alzheimers Dis. 2004;6:165-169.

Clegg A, Bryant J, Nicholson T, et al. Clinical and cost-effectiveness of donepezil, rivastigmine, and galantamine for Alzheimer's disease. A symptomatic review. Int J Technol Assess Health Care. 2002;18:497-507.

Courtney C, Farrell D, Gray R, et al; AD2000 Collaborative Group. Long-term donepezil treatment in 565 patients with Alzheimer's disease (AD2000): randomised double-blind trial. Lancet. 2004;363:2105-2115.

Cummings JL. Alzheimer's disease. N Engl J Med. 2004;351:56-67.

Cummings BJ, Cotman CW. Image analysis of beta-amyloid load in Alzheimer's disease and relation to dementia severity. Lancet. 1995;346:1524-1528.

DoH (Department of Health). Government response to NICE consultation on Alzheimer's drugs. London: Department of Health press release; March 22, 2005. DoH reference number 2005/0133. Available at:

http://www.dh.gov.uk/publicationsandstatistics/pressreleases/pressreleasesnoti ces/fs/en?content_ID=4106813\&CHK=/GTNRQ (accessed September 29, 2005).

Doody RS, Geldmacher DS, Gordon B, Perdomo CA, Pratt RD; Donepezil Study Group. Open-label, multicenter, phase 3 extension study of the safety and efficacy of donepezil in patients with Alzheimer disease. Arch Neurol. 2001a;58:427-433.

Doody RS, Stevens JC, Beck C, et al. Practice parameter: management of dementia (an evidence-based review). Report of the Quality Standards Subcommittee of the American Academy of Neurology. Neurology. 2001b;56:1154-1166.

Doody RS, Dunn JK, Clark CM, et al. Chronic donepezil treatment is associated with slowed cognitive decline in Alzheimer's disease. Dement Geriatr Cogn Disord. 2001c;12:295-300.

Evans DA, Funkenstein HH, Albert MS, et al. Prevalence of Alzheimer's disease in a community population of older persons. Higher than previously reported. JAMA. 1989;262:2551-2556.

Fagnani F, Lafuma A, Pechevis M, et al. Donepezil for the treatment of mild to moderate Alzheimer's disease in France: the economic implications. Dement Geriatr Cogn Disord. 2004;17:5-13.

Feldman H, Gauthier S, Hecker J, et al; Donepezil MSAD Study Investigators Group. Economic evaluation of donepezil in moderate to severe Alzheimer disease. Neurology. 2004;63:644-650.
Fernando MS, Ince PG; MRC Cognitive Function and Ageing Neuropathology Study Group. Vascular pathologies and cognition in a population-based cohort

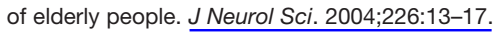

Fillit HM, Gutterman EM, Brooks RL. Impact of donepezil on caregiving burden for patients with Alzheimer's disease. Int Psychogeriatr. 2000;12:389-401.

Fillit H, Hill JW, Futterman R. Health care utilization and costs of Alzheimer's disease: the role of co-morbid conditions, disease stage, and pharmacotherapy. Fam Med. 2002;34:528-535.

Froelich L, Gertz H-J, Heun R, et al. Donepezil for Alzheimer's disease in clinical practice - the DONALD study. Dement Geriatr Cogn Disord. 2004;18:37-43.

Frölich L, Klinger T, Berger FM. Treatment with donepezil in Alzheimer patients with and without cerebrovascular disease. J Neurol Sci. 2002;203-204:137-139.

Gandy $\mathrm{S}$. The role of cerebral amyloid beta accumulation in common forms of Alzheimer disease. J Clin Invest. 2005;115:1121-1129.

Gasper MC, Ott BR, Lapane KL. Is donepezil therapy associated with reduced mortality in nursing home residents with dementia? Am J Geriatr Pharmacother. 2005;3:1-7.

Gauthier S, Feldman H, Hecker J, et al; Donepezil MSAD Study Investigators Group. Efficacy of donepezil on behavioral symptoms in patients with moderate to severe Alzheimer's disease. Int Psychogeriatr. 2002;14:389-404.

Geldmacher DS, Provenzano G, McRae T, Mastey V, leni JR. Donepezil is associated with delayed nursing home placement in patients with Alzheimer's disease. J Am Geriatr Soc. 2003;51:937-944.

Giacobini E. Cholinesterase inhibitors stabilize Alzheimer's disease. Ann NY Acad Sci. 2000;920:321-327.

Greenberg SM, Tennis MK, Brown LB, et al. Donepezil therapy in clinical practice: a randomized crossover study. Arch Neurol. 2000;57:94-99.

Hager K, Calabrese P, Frölich L, Göbel C, Berger FM. An observational clinical study of the efficacy and tolerability of donepezil in the treatment of Alzheimer's disease. Dement Geriatr Cogn Disord. 2003;15:189-198.

Hashimoto M, Kazui H, Matsumoto K, Nakano Y, Yasuda M, Mori E. Does donepezil treatment slow the progression of hippocampal atrophy in patients with Alzheimer's disease? Am J Psychiatry. 2005;162:676-682.

Hebert LE, Scherr PA, Bienias JL, Bennett DA, Evans DA. Alzheimer disease in the US population: prevalence estimates using the 2000 census. Arch Neurol. 2003;60:1119-1122.

Hegerl U, Mergl R, Henkel V, et al. Kinematic analysis of the effects of donepezil hydrochloride on hand motor function in patients with Alzheimer dementia. J Clin Psychopharmacol. 2003;23:214-216.

Hill JW, Futterman R, Mastrey V, Fillit H. The effect of donepezil therapy on health costs in a Medicare managed care plan. Manag Care Interface. 2002;15:63-70.

Holmes C, Burns A, Passmore P, Forsyth D, Wilkinson D. AD2000: design and conclusions. Lancet. 2004a;364:1213-1214.

Holmes C, Wilkinson D, Dean C, et al. The efficacy of donepezil in the treatment of neuropsychiatric symptoms in Alzheimer disease. Neurology. 2004b;63:214-219.

Homma A, Takeda M, Imai Y, et al. Clinical efficacy and safety of donepezil on cognitive and global function in patients with Alzheimer's disease. A 24-week, multicenter, double-blind, placebo-controlled study in Japan. E2020 Study Group. Dement Geriatr Cogn Disord. 2000;11:299-313.

Ikeda S, Yamada Y, Ikegami N. Economic evaluation of donepezil treatment for Alzheimer's disease in Japan. Dement Geriatr Cogn Disord. 2002;13:33-39.

Jackson S, Ham RJ, Wilkinson D. The safety and tolerability of donepezil in patients with Alzheimer's disease. Br J Clin Pharmacol. 2004;58(Suppl. 1):1-8. Jönsson L, Lindgren $P$, Wimo A, Jönsson B, Winblad B. The cost-effectiveness of donepezil therapy in Swedish patients with Alzheimer's disease: a Markov model. Clin Ther. 1999;21:1230-1240.

Katz S, Ford AS, Moscowitz RW, Jackson BA, Jaffe MW. Studies of illness in the aged. The index of ADL: a standardized measure of biological and psychosocial function. JAMA. 1963;185:914-919. 
Kemp PM, Holmes C, Hoffmann S, et al. A randomised placebo controlled study to assess the effects of cholinergic treatment on muscarinic receptors in Alzheimer's disease. $J$ Neurol Neurosurg Psychiatry. 2003;74:1567-1570.

Kinsella K, Velkoff VA. An aging world: 2001. Washington, DC: US Government Printing Office; 2001. US Census Bureau, Series P95/01-1. Available at: http://www.census.gov/prod/2001 pubs/p95-01-1.pdf (accessed September 29, 2005).

Klatte ET, Scharre DW, Nagaraja HN, Davis RA, Beversdorf DQ. Combination therapy of donepezil and vitamin E in Alzheimer disease. Alzheimer Dis Assoc Disord. 2003;17:113-116.

Koppel R. Alzheimer's disease: the costs to US businesses in 2002. Washington, DC: Alzheimer's Association; June 2002. Available at: http://www.alz.org/media/newsreleases/2002/062602ADCosts.pdf (accessed September 29, 2005).

Krishnan KR, Charles HC, Doraiswamy PM, et al. Randomized, placebocontrolled trial of the effects of donepezil on neuronal markers and hippocampal volumes in Alzheimer's disease. Am J Psychiatry. 2003;160:2003-2011.

Larson EB, Shadlen M-F, Wang L, et al. Survival after initial diagnosis of Alzheimer disease. Ann Intern Med. 2004:140:501-509.

Leung GM, Yeung RYT, Chi I, Chu LW. The economics of Alzheimer disease. Dement Geriatr Cogn Disord. 2003;15:34-43.

Liou YC, Sun A, Ryo A, et al. Role of the prolyl isomerase Pin1 in protecting against age-dependent neurodegeneration. Nature. 2003;424:556-561.

Lopez OL, Becker JT, Saxton J, Sweet RA, Klunk W, DeKosky ST. Alteration of a clinically meaningful outcome in the natural history of Alzheimer's disease by cholinesterase inhibition. J Am Geriatr Soc. 2005;53:83-87.

Loy C, Schneider L. Galantamine for Alzheimer's disease. Cochrane Database Syst Rev. 2004;(4):CD001747.

Lu S, Hill J, Fillit H. Impact of donepezil use in routine clinical practice on health care costs in patients with Alzheimer's disease and related dementias enrolled in a large Medicare managed care plan: a case control study. Am J Geriatr Pharmacother. 2005;3:92-102.

Mohs RC, Doody RS, Morris JC, et al; 312 Study Group. A 1-year, placebocontrolled preservation of function survival study of donepezil in $A D$ patients. Neurology. 2001;57:481-488.

Mossello E, Tonon E, Caleri V, et al. Effectiveness and safety of cholinesterase inhibitors in elderly subjects with Alzheimer's disease: a "real world" study. Arch Gerontol Geriatr Suppl. 2004;(9):297-307.

Nakano S, Asada T, Matsuda H, Uno M, Takasaki M. Donepezil hydrochloride preserves regional cerebral blood flow in patients with Alzheimer's disease. J Nucl Med. 2001;42:1441-1445.

Neumann PJ, Hermann RC, Kuntz KM, et al. Cost-effectiveness of donepezil in the treatment of mild or moderate Alzheimer's disease. Neurology. 1999;52:1138-1145.

NICE (National Institute for Health and Clinical Excellence). Appraisal Consultation Document. Donepezil, rivastigmine, galantamine and memantine for the treatment of Alzheimer's disease. London: National Institute for Health and Clinical Excellence; March 2005. Available at:

http://www.nice.org.uk/page.aspx?o=245909 (accessed September 29, 2005).

NICE (National Institute for Health and Clinical Excellence). Appraisal Consultation Document. Donepezil, galantamine, rivastigmine (review) and memantine for the treatment of Alzheimer's disease. London: National Institute for Health and Clinical Excellence; January 2006. Available at: http://www.nice.org.uk/page.aspx?o=288878 (accessed January 23, 2006).

Nobili $F$, Vitali $P$, Canfora $M$, et al. Effects of long-term donepezil therapy on rCBF of Alzheimer's patients. Clin Neurophysiol. 2002;113:1241-1248.

O'Brien BJ, Goeree R, Hux M, et al. Economic evaluation of donepezil for the treatment of Alzheimer's disease in Canada. $J$ Am Geriatr Soc.

1999;47:570-578.

Onofrj M, Thomas A, lacono D, Luciano AL, Di lorio A. The effects of a cholinesterase inhibitor are prominent in patients with fluctuating cognition: a part 3 study of the main mechanism of cholinesterase inhibitors in dementia. Clin Neuropharmacol. 2003;26:239-251.
Palmer AM, Stratmann GC, Procter AW, Bowen DM. Possible neurotransmitter basis of behavioral changes in Alzheimer's disease. Ann Neurol. 1988;23:616-620. Pappas BA, Bayley PJ, Bui BK, Hansen LA, Thal LJ. Choline acetyltransferase activity and cognitive domain scores of Alzheimer's patients. Neurobiol Aging. 2000;21:11-17.

Perry EK, Tomlinson BE, Blessed G, Bergmann K, Gibson PH, Perry RH. Correlation of cholinergic abnormalities with senile plaques and mental test scores in senile dementia. Br Med J. 1978;2:1457-1459.

Petersen RC, Thomas RG, Grundman M, et al; Alzheimer's Disease Cooperative Study Group. Vitamin E and donepezil for the treatment of mild cognitive impairment. N Engl J Med. 2005;352;2379-2388.

Pryse-Phillips W, Sternberg S, Rochon P, Naglie G, Strong H, Feightner J. The use of medications for cognitive enhancement. Can J Neurol Sci. 2001;28(Suppl. 1):S108-S114.

Rabins PV. Guideline watch: practice guideline for the treatment of patients with Alzheimer's disease and other dementias of late life. Arlington, VA: American Psychiatric Association; August 2004. Available at:

http://www.psych.org/psych_pract/treatg/pg/alzwatch_081704.pdf (accessed September 29, 2005).

RCP (Royal College of Psychiatrists). Royal College of Psychiatrists' response to the proposal to the National Institute of Clinical Excellence (NICE) to withdraw treatments for Alzheimer's disease from the NHS - college strongly disagrees with preliminary recommendations. London: Royal College of Psychiatrists press release; 2005. Available at:

http://www.rcpsych.ac.uk/press/preleases/pr/pr_653.htm (accessed September 29, 2005).

Relkin NR, Reichman WE, Orazem J, McRae T. A large, community-based, open-label trial of donepezil in the treatment of Alzheimer's disease. Dement Geriatr Cogn Disord. 2003;16:15-24.

Requena C, López Ibor MI, Maestú F, Campo P, López Ibor JJ, Ortiz T. Effects of cholinergic drugs and cognitive training on dementia. Dement Geriatr Cogn Disord. 2004;18:50-54.

Ringheim GE, Conant K. Neurodegenerative disease and the neuroimmune axis (Alzheimer's and Parkinson's disease, and viral infections). $\mathbf{J}$ Neuroimmunol. 2004;147:43-49.

Rockwood K, Graham JE, Fay S; ACADIE Investigators. Goal setting and attainment in Alzheimer's disease patients treated with donepezil. $J$ Neurol Neurosurg Psychiatry. 2002;73:500-507.

Rodriguez G, Vitali P, De Leo C, De Carli F, Girtler N, Nobili F. Quantitative EEG changes in Alzheimer patients during long-term donepezil therapy.

Neuropsychobiology. 2002;46:49-56.

Rogers SL, Friedhoff LT. The efficacy and safety of donepezil in patients with Alzheimer's disease: results of a US multicentre, randomized, double-blind, placebo-controlled trial. The Donepezil Study Group. Dementia. 1996;7:293-303.

Rogers SL, Friedhoff LT. Long-term efficacy and safety of donepezil in the treatment of Alzheimer's disease: an interim analysis of the results of a US multicentre open label extension study. Eur Neuropsychopharmacol. 1998;8:67-75.

Rogers SL, Doody RS, Mohs RC, Friedhoff LT. Donepezil improves cognition and global function in Alzheimer disease: a 15-week, double-blind, placebocontrolled study. Donepezil Study Group. Arch Intern Med. 1998a;158:1021-1031.

Rogers SL, Farlow MR, Doody RS, Mohs R, Friedhoff LT. A 24-week, doubleblind, placebo-controlled trial of donepezil in patients with Alzheimer's disease. Donepezil Study Group. Neurology. 1998b;50:136-145.

Rogers SL, Doody RS, Pratt RD, leni JR. Long-term efficacy and safety of donepezil in the treatment of Alzheimer's disease: final analysis of a US multicentre open-label study. Eur Neuropsychopharmacol. 2000;10:195-203.

Saine K, Cullum CM, Martin-Cook K, Hynan L, Svetlik DA, Weiner MF. Comparison of functional and cognitive donepezil effects in Alzheimer's disease. Int Psychogeriatr. 2002;14:181-185.

Salloway S, Ferris S, Kluger A, et al; Donepezil 401 Study Group. Efficacy of donepezil in mild cognitive impairment: a randomized placebo-controlled trial. Neurology. 2004;63:651-657. 
Santens $\mathrm{P}$, Ventura M. Donepezil in the treatment of mild to moderate Alzheimer's disease: report of a Belgian multicentre study. Acta Neurol Belg. 2003;103:159-163.

Seltzer B, Zolnouni P, Nunez M, et al; Donepezil 402 Study Group. Efficacy of donepezil in early-stage Alzheimer disease: a randomized placebo-controlled trial. Arch Neurol. 2004;61:1852-1856.

St George-Hyslop PH. Piecing together Alzheimer's. Sci Am. 2000;283:76-83.

Tabet N, Birks J, Grimley Evans J, Orrel M, Spector A. Vitamin E for Alzheimer's disease. Cochrane Database Syst Rev. 2000;(4):CD002854.

Tanaka M, Namiki C, Ha Duy Thuy D, et al. Prediction of psychiatric response to donepezil in patients with mild to moderate Alzheimer's disease. J Neurol Sci. 2004;225:135-141.

Tariot PN, Cummings JL, Katz IR, et al. A randomized, double-blind, placebocontrolled study of the efficacy and safety of donepezil in patients with Alzheimer's disease in the nursing home setting. J Am Geriatr Soc. 2001;49:1590-1599.

Tune L, Tiseo PJ, leni J, et al. Donepezil HCl (E2020) maintains functional brain activity in patients with Alzheimer disease: results of a 24-week, double-blind, placebo-controlled study. Am J Geriatr Psychiatry. 2003;11:169-177.

Warner J, Butler R, Arya P. Dementia. Clin Evid. 2004;(12):1361-1390.

Whitehead A, Perdomo C, Pratt RD, Birks J, Wilcock GK, Grimley Evans J. Donepezil for the symptomatic treatment of patients with mild to moderate Alzheimer's disease: a meta-analysis of individual patient data from randomised controlled trials. Int J Geriatr Psychiatry. 2004;19:624-633.

Wilcock G, Howe I, Coles H, et al; GAL-GBR-2 Study Group. A long-term comparison of galantamine and donepezil in the treatment of Alzheimer's disease. Drugs Aging. 2003;20:777-789.

Wilkinson DG, Passmore AP, Bullock R, et al. A multinational, randomised, 12week, comparative study of donepezil and rivastigmine in patients with mild to moderate Alzheimer's disease. Int J Clin Pract. 2002;56:441-446.

Wimo A. Cost effectiveness of cholinesterase inhibitors in the treatment of Alzheimer's disease: a review with methodological considerations. Drugs Aging. 2004;21:279-295.
Wimo A, Winblad B, Aguero-Torres H, von Strauss E. The magnitude of dementia occurrence in the world. Alzheimer Dis Assoc Disord. 2003a;17:63-67.

Wimo A, Winblad B, Engedal K, et al; Donepezil Nordic Study Group. An economic evaluation of donepezil in mild to moderate Alzheimer's disease: results of a 1-year, double-blind, randomized trial. Dement Geriatr Cogn Disord. 2003b;15:44-54.

Wimo A, Winblad B, Shah SN, Chin W, Zhang R, McRae T. Impact of donepezil treatment for Alzheimer's disease on caregiver time. Curr Med Res Opin. 2004;20:1221-1225.

Winblad B, Engedal K, Soininen H, et al; Donepezil Nordic Study Group. A 1-year, randomized, placebo-controlled study of donepezil in patients with mild to moderate AD. Neurology. 2001;57:489-495.

Wolfson C, Moride Y, Perrault A, Momoli F, Demers L, Oremus M. Drug treatments for Alzheimer's disease. II. A review of outcome measures in clinical trials. Ottawa: Canadian Coordinating Office for Health Technology Assessment (CCOHTA); May 2000. Available at: http://www.ccohta.ca/entry_e.html (accessed September 29, 2005).

Wolfson C, Oremus M, Shukla V, et al. Donepezil and rivastigmine in the treatment of Alzheimer's disease: a best-evidence synthesis of the published data on their efficacy and cost-effectiveness. Clin Ther. 2002;24:862-885.

WHO (World Health Organization). The world health report 2001. Mental health: new understanding, new hope. Geneva: World Health Organisation; 2001. Available at: http://www.who.int/whr/2001/en/whr01_en.pdf (accessed September 29, 2005).

Zlokovic BV, Deane R, Sallstrom J, Chow N, Miano JM. Neurovascular pathways and Alzheimer amyloid beta-peptide. Brain Pathol. 2005;15:78-83.

Correspondence: Joanne Knowles, Core Medical Publishing, Mere House, Brook Street, Knutsford, Cheshire WA16 8GP, UK or at editor@coreevidence.com 